\title{
Variability in Rainfall at Monitoring Stations and Derivation of a Long-Term Rainfall Intensity Record in the Grand Canyon Region, Arizona, USA
}

Scientific Investigations Report 2016-5012 
Cover: Storm clouds upstream of Whitmore Wash in Grand Canyon, Arizona. Photograph by Joshua Caster, U.S. Geological Survey, 2014. 


\section{Variability in Rainfall at Monitoring Stations and Derivation of a Long-Term Rainfall Intensity Record in the Grand Canyon Region, Arizona, USA}

By Joshua Caster and Joel B. Sankey

Scientific Investigations Report 2016-5012 


\title{
U.S. Department of the Interior SALLY JEWELL, Secretary
}

\section{U.S. Geological Survey Suzette M. Kimball, Director}

\author{
U.S. Geological Survey, Reston, Virginia: 2016
}

For more information on the USGS - the Federal source for science about the Earth, its natural and living resources, natural hazards, and the environment—visit http://www.usgs.gov or call 1-888-ASK-USGS.

For an overview of USGS information products, including maps, imagery, and publications, visit http://www.usgs.gov/pubprod/.

Any use of trade, firm, or product names is for descriptive purposes only and does not imply endorsement by the U.S. Government.

Although this information product, for the most part, is in the public domain, it also may contain copyrighted materials as noted in the text. Permission to reproduce copyrighted items must be secured from the copyright owner.

Suggested citation:

Caster, Joshua, and Sankey, J.B., 2016, Variability in rainfall at monitoring stations and derivation of a long-term rainfall intensity record in the Grand Canyon region, Arizona, USA: U.S. Geological Survey Scientific Investigations Report 2016-5012, 38 p., http://dx.doi.org/10.3133/sir20165012.

ISSN 2328-0328 (online) 


\section{Contents}

Abstract Introduction.
Materials and Methods
Grand Canyon Monitoring and Research Center Inner Canyon Stations (GICS)
$\quad$ Marble Canyon Gauge Network (MCGN and MCGN-Kaibab)
SOAA Cooperative Observer Stations (NOAA COOP)
Short-Term Spatial Rainfall Variability
Long-Term Rainfall Depth Variability
Results
$\quad$ Short-Term Spatial Rainfall Variability
Long-Term Rainfall Depth Variability

\section{Figures}

1. Map showing the locations of weather data collection sites...........................................

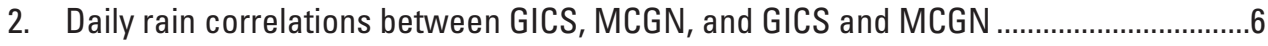

3. Spatial distribution of rainfall for 2008-10 ..............................................................

4. Relation of 2008-10 station rainfall by elevation and seasonal rainfall regime ..................... 8

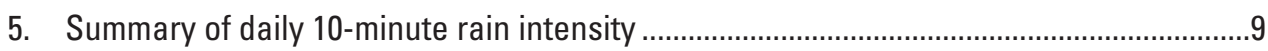

6. Mean annual number of days that were above daily rainfall percentile and associated median 10-minute intensities .............................................................................................11

7. Annual, cool-season, and warm-season rainfall for 1950-2012 ....................................12

8. Depth-intensity relation based on cool-, dry-, and warm-season equations....................14

9. Comparison of predicted and observed maximum daily 10-minute intensities ...............17

10. Predicted maximum daily 10-minute rainfall intensity .....................................................18

11. National Weather Service time series of composite radar coverage over Marble and Grand Canyons on August 8, 2008............................................................................20

12. Time series plot showing cumulative rainfall and rainfall intensity during the summer of 2013. 


\section{Tables}

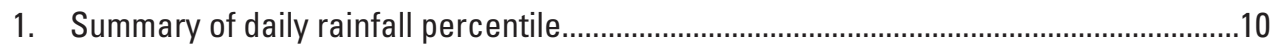

2. Results of a linear regression of annual and seasonal rainfall .......................................13

3. Regression results for log-transformed, daily rainfall depth and daily maximum 10-minute intensity

4. Results of an Akaike Information Criterion evaluation of modeled daily 10-minute intensity.

\section{Appendixes}

1. National Ocean and Atmospheric Administration Cooperative Observer Stations within the Grand Canyon Region.

2. Akaike Information Criteria Calculation Results for Multi-Station Geographic Groups .30

3. Plot of rainfall depth-intensity relation for multi-station geographic groups ... 36

4. Estimated maximum daily rainfall intensity at National Oceanic and Atmospheric Cooperative Observer Stations (NOAA COOP) Phantom Ranch and Lees Ferry [Available online only]

\section{Conversion Factors}

English Units to SI Units

\begin{tabular}{lcll}
\hline & Multiply & & \multicolumn{1}{c}{ By } \\
\hline inch (in.) & 25.4 & To obtain \\
foot (ft) & 0.305 & millimeter $(\mathrm{mm})$ \\
mile (mi) & 1.609 & kilometer $(\mathrm{km})$ \\
\hline
\end{tabular}

SI Units to English Units

\begin{tabular}{llll}
\hline \multicolumn{1}{c}{ Multiply } & \multicolumn{1}{c}{ By } & \multicolumn{1}{c}{ To obtain } \\
\hline millimeter $(\mathrm{mm})$ & 0.03937 & inch (in.) & \\
meter $(\mathrm{m})$ & 3.281 & foot (ft) & \\
\hline
\end{tabular}




\title{
Variability in Rainfall at Monitoring Stations and Derivation of a Long-Term Rainfall Intensity Record in the Grand Canyon Region, Arizona, USA
}

\author{
By Joshua Caster and Joel B. Sankey
}

\section{Abstract}

In this study, we examine rainfall datasets of varying temporal length, resolution, and spatial distribution to characterize rainfall depth, intensity, and seasonality for monitoring stations along the Colorado River within Marble and Grand Canyons. We identify maximum separation distances between stations at which rainfall measurements might be most useful for inferring rainfall characteristics at other locations. We demonstrate a method for applying relations between daily rainfall depth and intensity, from short-term high-resolution data to lower-resolution longer-term data, to synthesize a long-term record of daily rainfall intensity from 1950-2012. We consider the implications of our spatio-temporal characterization of rainfall for understanding local landscape change in sedimentary deposits and archaeological sites, and for better characterizing past and present rainfall and its potential role in overland flow erosion within the canyons. We find that rainfall measured at stations within the river corridor is spatially correlated at separation distances of tens of kilometers, and is not correlated at the large elevation differences that separate stations along the Colorado River from stations above the canyon rim. These results provide guidance for reasonable separation distances at which rainfall measurements at stations within the Grand Canyon region might be used to infer rainfall at other nearby locations along the river. Like other rugged landscapes, spatial variability between rainfall measured at monitoring stations appears to be influenced by canyon and rim physiography and elevation, with preliminary results suggesting the highest elevation landform in the region, the Kaibab Plateau, may function as an important orographic influence. Stations at specific locations within the canyons and along the river, such as in southern (lower) Marble Canyon and eastern (upper) Grand Canyon, appear to have strong potential to receive high-intensity rainfall that can generate runoff which may erode alluvium. The characterization of past and present rainfall variability in this study will be useful for future studies that evaluate more spatially continuous datasets in order to better understand the rainfall dynamics within this, and potentially other, deep canyons.

\section{Introduction}

The Grand Canyon region (fig. 1) is an iconic dryland environment with complex geologic and biophysical characteristics that are ever changing in response to weather and climate. Long-term monitoring of discharge and sediment loads of the Colorado River and its tributaries, as well as monitoring of rainfall at the headwaters of the tributary watersheds, are integral to tracking the physical evolution of the river channel and riparian zone within Marble and Grand Canyons (Topping and others, 2000; Webb and others, 2000; Griffiths and others, 2014). For those areas within the canyons that are not in the riparian zone or active river channel, the physical evolution of the landscape is predominantly driven by local and regional weather conditions, specifically rainfall-induced overland flow (rainfall runoff; Hereford and others, 1993; Draut and Rubin, 2008; Draut, 2012; Schott and others, 2014; Pederson and O'Brien, 2014). For example, erosion induced by rainfall runoff at archaeological sites that are located on river terraces, debris fans, and hillslopes bordering the Colorado River within Grand Canyon National Park has been well documented (Jones, 1986; Hereford and others, 1993; Fairley and others, 1994; Pederson and O'Brien, 2014), particularly after intervals of multiple years with aboveaverage rainfall within the region (Hereford and others, 1993, 2014). Although rainfall is not the only factor in the production of runoff, characterization of rain depth, intensity, and timing (seasonality) are useful for understanding the potential generation of rainfall runoff, both dependent and independent of other physiographic factors. Quantification of the spatial and temporal variability of these rainfall variables is therefore essential to understanding the mechanisms that control past, present, and future runoff erosion. By examining rainfall characteristics from the available data in the Grand Canyon region, we can better assess the potential effects of rain variability on overland flow erosion, and begin to explore its influence on local landscapes within Marble and Grand Canyons. 


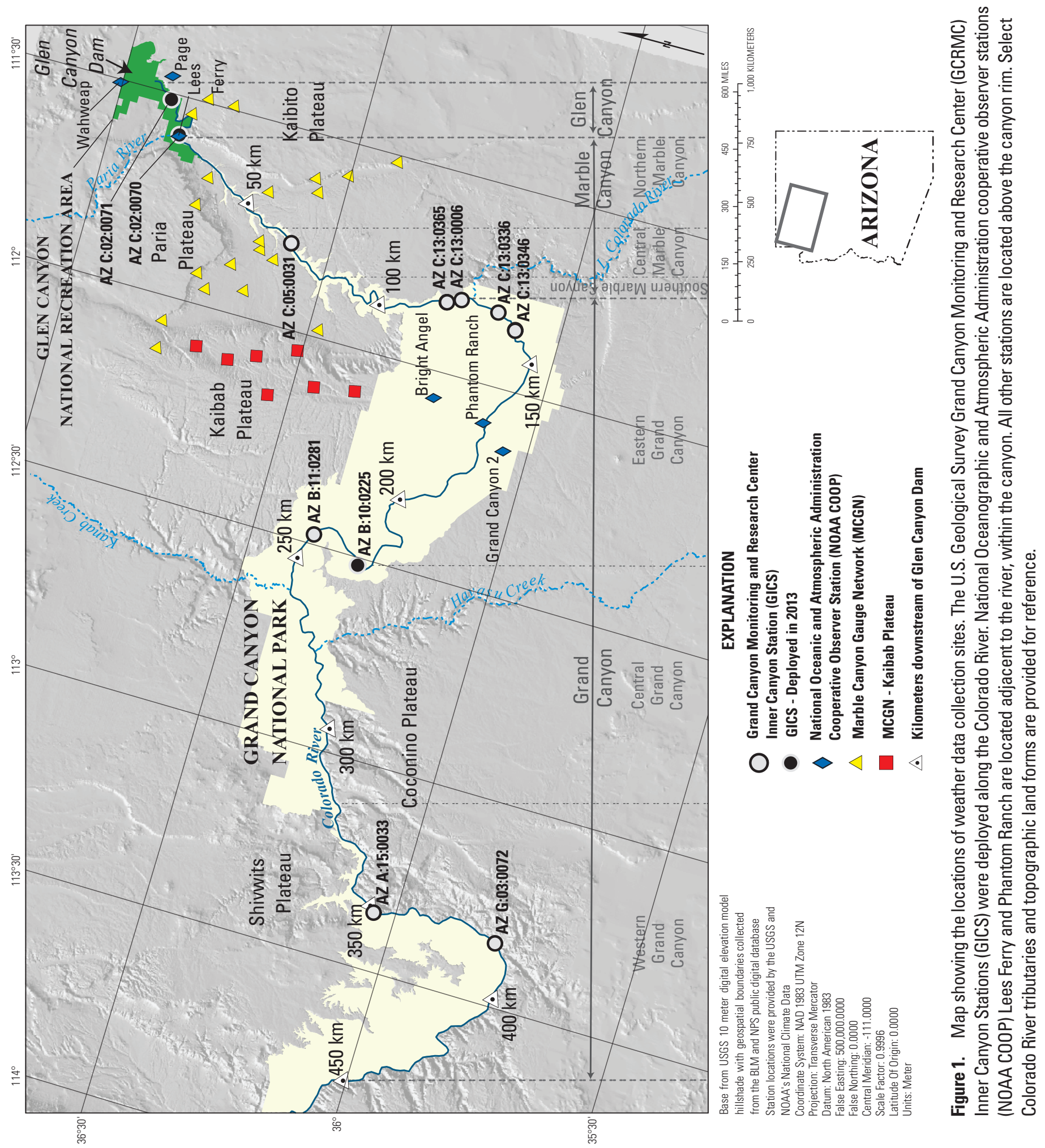


The longest time period of available rainfall records within the Grand Canyon region are from National Oceanographic and Atmospheric Administration (NOAA) cooperative observer stations (Hereford and others, 2014). While several NOAA stations are located within the region and above the rim of Marble or Grand Canyons, two NOAA stations are located along the Colorado River (fig. 1). The two station locations, Phantom Ranch in Grand Canyon and Lees Ferry near the boundary of Glen and Marble Canyons, have been in concurrent operation since 1933. These stations record multiple parameters including daily rainfall depth. Whereas these data are invaluable for understanding past rainfall at coarse temporal resolution, the data resolution is not sufficient to assess subdaily rainfall characteristics such as event-based intensity. Moreover, the two station locations are not sufficient to assess spatial variability of rainfall within the canyons and it is unclear how nearby locations outside of the canyons, above the rims, might represent inner-canyon conditions. Additional monitoring efforts at more locations have provided highresolution weather data that are more sufficient to characterize subdaily variability in rainfall (Draut and others, 2009a,b, 2010; Caster and others, 2014; Griffiths and others, 2014). These datasets are not spatially continuous (fig. 1), nor are they as temporally rich as the long-term cooperative observer stations (Draut and others, 2009a), but they do provide the best observational data currently available. In this study, we build upon previous work (Griffiths and others, 2014; Hereford and others, 2014) to integrate monitoring datasets that vary in length, resolution, and spatial coverage in order to characterize temporal and spatial variability in rainfall depth, intensity, and timing at stations in the Grand Canyon region. We identify maximum separation distances between stations at which rainfall measurements might be most useful for inferring rainfall at other locations. We consider the implications of our spatio-temporal characterization of rainfall for understanding landscape change in sediment deposits and archaeological sites of the river corridor and for better characterizing past, present, and future rainfall and runoff potential.

\section{Materials and Methods}

Rainfall data were compiled for analysis from three sources of monitoring data with unique spatial distribution, data resolution, and period of record across the study area. For this study, the region of interest focused on the river corridor downstream of Glen Canyon Dam within Marble and Grand Canyons, and a part of Glen Canyon (fig. 1) (heretofore and hereafter the Grand Canyon region). For the purposes of discussion, Marble Canyon has been divided into three subsections: northern (upper) Marble Canyon, from Lees Ferry, Arizona to approximately $60 \mathrm{~km}$ (37.5 miles) downstream of Glen Canyon Dam; central Marble Canyon, between approximately $60 \mathrm{~km}$ and $112 \mathrm{~km}$ (70 miles) downstream of Glen Canyon Dam; and southern (lower) Marble Canyon, between $115 \mathrm{~km}$ downstream of Glen Canyon Dam and the confluence with the Little Colorado River (approximately 78 miles downstream of Glen Canyon Dam; fig. 1). Similarly, Grand Canyon was subdivided into three reaches: eastern (upper) Grand Canyon, from the terminus of southern Marble Canyon (at the confluence with the Little Colorado River) to approximately $225 \mathrm{~km}$ (140.5 miles) downstream of Glen Canyon Dam; central Grand Canyon, from approximately $225 \mathrm{~km}$ to $325 \mathrm{~km}$ (203 miles) downstream of Glen Canyon Dam; and western (lower) Grand Canyon, from approximately $325 \mathrm{~km}$ to $450 \mathrm{~km}$ (281 miles) downstream of Glen Canyon Dam (fig. 1).

\section{Grand Canyon Monitoring and Research Center Inner Canyon Stations (GICS)}

In 2007-08, the U.S. Geological Survey (USGS) Grand Canyon Monitoring and Research Center (GCMRC) deployed 11 automated weather stations at 8 monitoring stations distributed across $320 \mathrm{~km}$ of the Colorado River. Each of these stations is adjacent to the river and located within either Marble Canyon or Grand Canyon. Five of the monitoring stations were located near previous rain gauges in operation between 2003-06 (Draut and Rubin, 2005, 2006). The 11 automated weather stations used in this study incorporated a Vaisala WX510/520 transmitter to record air temperature, barometric pressure, precipitation, relative humidity, wind speed, and wind direction at four-minute intervals (Draut and others, 2009a,b, 2010; Dealy and others, 2014; Caster and others, 2014) from 2007-10. The Vaisala transmitter uses a piezoelectric sensor to collect rainfall depth at a submillimeter resolution. Following a two-year hiatus at the eight monitoring stations in 2011-12, data collection resumed at three existing monitoring stations and began at three new monitoring stations; data were recorded at those six stations beginning in 2013 and continuing as of this writing (2015; fig. 1; Caster and others, 2014).

\section{Marble Canyon Gauge Network (MCGN and MCGN-Kaibab)}

GCMRC also maintains a network of 29 tipping-bucket rain gauges that were deployed in the early 2000s around Marble Canyon and record rainfall depths $\geq 0.254 \mathrm{~mm}$ (Griffiths and others, 2014). Most of these gauges are located above the canyon rim along tributaries of the Colorado River, however, six are located just below the rim and one, in Glen Canyon, is located near the river (Griffiths and others, 2014). Of the 29 gauges, 25 were selected for this study based on spatial distribution and operation periods. Eighteen of the gauges used in this study are located at lower elevations east of the Kaibab Plateau (henceforth MCGN), and seven of the gauges are located at higher elevations on the Kaibab Plateau (henceforth MCGN-Kaibab). 


\section{NOAA Cooperative Observer Stations (NOAA COOP)}

The National Weather Service (NWS), part of the National Oceanographic and Atmospheric Administration (NOAA), maintains numerous cooperative observer program (COOP) stations on the Colorado Plateau. There are 30 NOAA COOP stations in the Grand Canyon region (appendix 1) with a combined record extending back to 1915 (Hereford and others, 2014). There are four NOAA COOP stations that are either adjacent to, or within, Glen, Marble, or Grand Canyons that have concurrent data extending back to the 1960s. Two of those four stations are situated at substantially higher elevations above the rims of Glen and Grand Canyons. The other two stations, Lees Ferry and Phantom Ranch, are adjacent to the Colorado River (fig.1) and have a longer period of record, but are located in significantly different parts of the river corridor in terms of canyon physiography. The Lees Ferry station is at the upstream end of Marble Canyon in a relatively open area between Marble and Glen Canyons. The Phantom Ranch station is in the Inner Gorge of Grand Canyon, a reach characterized by steep canyon walls and a narrower river channel. Both stations have been subject to minor location changes (Lees Ferry in 1965 and again in 1991; Phantom Ranch in 1966) but have been located in the same general areas since 1950. Rainfall records are typically collected using a standard $203.2 \mathrm{~mm}$ (8-inch) rain gauge (SRG) tube and are recorded daily at a resolution of $0.254 \mathrm{~mm}$ (National Oceanographic and Atmospheric Administration, 2014).

\section{Short-Term Spatial Rainfall Variability}

Spatial variability in daily rainfall was analyzed for the GICS and MCGN datasets acquired between 2007-10, a period representing the largest spatial dataset of rainfall monitoring stations operating concurrently within Marble and Grand Canyons. Pearson correlation coefficients were determined for daily rainfall between concurrently operating stations, omitting days with no recorded data (owing to occasional equipment malfunction) and omitting days when no rain was observed at every station within each dataset (in other words, for a given day, data were included for all stations as long as all stations were operational and at least one station received rain). Correlation was analyzed as a function of horizontal (Euclidean without regard to vertical difference) and vertical (elevation) separation distances between stations. The relationships for daily rainfall between each station were heteroscedastic, with a greater variance near the low range of daily rainfall (daily rain accumulations at or near zero). The heteroscedasticity was at least partly due to the fact that the data contained days with no rain and days with rainfall. To be conservative, only Pearson correlation coefficients greater than or equal to 0.8 were considered correlated, and coefficients greater than or equal to 0.9 were considered strongly correlated.
Spatial variability of seasonal and annual rainfall was analyzed for all data acquired at the GICS stations and the Lees Ferry and Phantom Ranch NOAA COOP stations (henceforth collectively referred to as river stations). Analysis of seasonal and annual rainfall was restricted to rainfall recorded during 2008-10 when stations operated concurrently for more than 90 percent of the days; staggered installation and maintenance issues at GICS sites did not provide comparably consistent and concurrent records during 2007 (Draut and others, 2009a; Caster and others, 2014). The mean rainfall by season for the 3-year interval from 2008 to 2010 was calculated for each station. Seasons were defined as dry season from April 1 to June 30, warm season (in other words, summer thunderstorm season) from July 1 to October 7, and cool season from October 8 through March 31 of the following calendar year (Hereford and others, 2014).

The mean annual rainfall, and the ratio of warm season to cool season rainfall (warm:cool), were calculated for the 2008-10 time period for each station in all datasets (GICS, MCGN, MCGN-Kaibab, NOAA COOP). The annual rainfall was determined from October 8 of the previous year to October 7 of the stated year. Spatial variability in rainfall was examined by plotting the ratio of warm to cool season means as a function of mean annual rainfall for (1) the river stations (all GICS, and the Lees Ferry and Phantom Ranch NOAA COOP stations), and (2) the rim stations (MCGN, MCGN-Kaibab, and all other NOAA COOP stations).

Similar to the analysis of daily rainfall, spatial variability in rain intensity within Marble and Grand Canyons was assessed for GICS during 2008-10. Analysis focused on 10-minute rainfall intensity, a common intensity measure that retains intrastorm characteristics (Farmer and Fletcher, 1972) and has been linked to localized rainfall runoff in rugged terrains (Hadley and Lusby, 1967; Robichaud and others, 2009). Daily maximum 10-minute intensities $\left(I_{10}\right)$ were compared to the 99 and 99.9 percentile of combined GICS 3-year daily rainfall. The 99 and 99.9 percentiles are measures that have been shown to be related to heavy rainfall with strong potential to initiate overland flow (Groisman and others, 2001, 2005). We calculated the median of the $I_{10}$ values for rainfall above the 99 and 99.9 percentile and considered the results as potential thresholds for exceedance of typical infiltration and induction of runoff. This method has the potential to separately identify daily rainfall of high intensityshort duration storms (for example, $>99$ percentile rainfall with $I_{10} \geq$ median values) typical of warm season thunderstorms from low intensity-long duration storms (for example, $>99$ percentile rainfall with $I_{10}<$ median values), typical of the cool season. For this study, high-intensity, short-duration rainfall was considered the most probable precipitation event to generate runoff, though we acknowledge that low-intensity, long-duration rainfall, particularly with higher antecedent soil moisture, could also generate runoff (Baartman and others, 2012). The frequency of days above these thresholds ( $>99$ and 99.9 percentile rainfall with $I_{10} \geq$ median values) was used to investigate the approximate recurrence interval of these events during the 3-year assessment period. 


\section{Long-Term Rainfall Depth Variability}

Temporal variability in rainfall amount (depth) was evaluated for the Phantom Ranch and Lees Ferry NOAA COOP stations, as well as the mean rainfall calculated from the other 28 NOAA COOP stations in the greater Grand Canyon region (Hereford and others, 2014; appendix 1). Seasonal and annual rainfall was summarized for years with at least 80 percent, or 292 days out of 365 days within one year (366 in a leap year), of the possible number of records collected during 1950 through 2012. Using the rainfall summaries, a simple linear regression was used to determine how well rainfall patterns within the canyon were explained by the aggregated regional (mean of the 28 NOAA COOP stations) weather records. In this analysis we investigate potential deviations from the regional rainfall pattern. We did not explore regional patterns through additional analysis of individual NOAA COOP stations or various aggregations (subsets) of regional stations and climatic circulation indicators, such as the El Niño/ La Niña Southern Oscillation (ENSO) or Pacific Decadal Oscillation (PDO) indices, as considerable work has been done on this subject (Hereford and Webb, 1992; Hereford and others, 2014).

\section{Long-Term Rainfall Intensity Variability}

NOAA COOP stations in the canyon record only daily rainfall totals, which do not permit the direct calculation of 10-minute rainfall intensities. In order to estimate long-term rainfall intensity at NOAA COOP stations using daily rainfall depth measurements, rain intensity was analyzed as a function of rain depth for GICS, MCGN, and MCGN-Kaibab records collected from 2007-10. The rain depth-intensity relation was defined by comparing daily rainfall (depth) to maximum daily 10-minute intensity. Both variables are highly right skewed (skewness $=\sim 3.5$ ), so they were transformed using the natural $\log$ to reduce this skewness (skewness $\leq-0.1$ ) to an approximate normal distribution. The transformed data were analyzed with a linear regression considering the cool, dry, and warm season data separately. Some heteroscedasticity is inherent in the lower range of values (daily rainfall depths below $0.25 \mathrm{~mm}$ ) given the nature of the depth-intensity relation when rainfall nears $0 \mathrm{~mm}$. Given this fact, results are expected to underpredict intensity values for high daily rainfall depths (rainfall greater than $10 \mathrm{~mm}$ ), though this effect is likely minimal as values above $0.25 \mathrm{~mm}$ were significantly homoscedastic (Beusch-Pagan P-value $>0.05$ ).

Regression equations from a sample of 21 individual stations (5 GICS, 11 MCGN, and 5 MCGN-Kaibab) with near uniform (in other words, nonclustered) spatial distribution were compared to station group regression equations that were aggregated by geography (GICS, MCGN, or MCGN-Kaibab) and season (cool, dry, warm) using Akaike Information Criteria (AIC), a statistical method used to evaluate how well two or more models predict values based on the number of parameters and a measure of likelihood (Akaike, 1974):

$$
A I C=2 k-2 \ln (L),
$$

where $k$ is the number of parameters, and $L$ is the value of the likelihood function calculated from model residuals.

Between the individual stations and the geographic groups, we considered the model with the lowest AIC to be the best single predictor of 10 -minute intensity. Models with $\triangle \mathrm{AIC}$ less than 2.0 were considered to be statistically similar to the best model (where $\triangle \mathrm{AIC}$ is the difference between the model AIC and the lowest AIC). Models with $\triangle \mathrm{AIC}$ less than 5.0 were also considered to be similar - though less strongly - to the best model. Models with $\triangle \mathrm{AIC}$ greater than 5.0 were considered to be significantly different than the best model.

Rainfall depth totals were not directly comparable between GICS and MCGN stations, because the two types of weather stations use different methods of measurement. To compare data from GICS and MCGN stations, we applied a simple correction factor (equation 2) based on Basara and others (2009) comparison of the piezoelectric sensor and tipping-bucket rain gauge:

$$
\text { GICS }_{\text {corr }}=0.74 \times \text { GICS }_{\text {raw }} \text {, }
$$

where GICS $_{\text {corr }}$ are the piezoelectric sensor data that have been corrected to be comparable to rain gauge data, and GICS $_{\text {raw }}$ are the collected piezoelectric sensor data.

We validated the best regression equations for the inner canyon by comparing predicted and observed rainfall intensity for 2013-14 (independent validation data that were not used for model calibration). After validation, we used the best models to estimate daily maximum rain intensity at the Phantom Ranch and Lees Ferry NOAA COOP river stations for 1950-2012. We summarized the modeled values by the median $I_{10}$ calculated from the 99 and 99.9 daily rainfall totals, termed the $99-I_{10}$ and $999-I_{10}$, respectively.

\section{Results}

\section{Short-Term Spatial Rainfall Variability}

The strength of the correlation for daily rainfall depth measured at pairs of weather stations varied as a function of the horizontal distance and elevation difference between the stations (fig. 2). Few stations were strongly correlated (correlation coefficient $>0.9$ ). However, most stations shared between 75 to 90 percent of days with concurrent rainfall or no recorded rainfall. When only days with high rainfall ( $>10 \mathrm{~mm}$ per day) observed concurrently between stations were considered, stations with correlation coefficients greater than 0.8 typically shared between 65 and 75 percent of days with concurrent high rainfall. Stations with coefficients between 0.5 and 0.8 typically shared between 50 and 65 percent of concurrent high rainfall. 

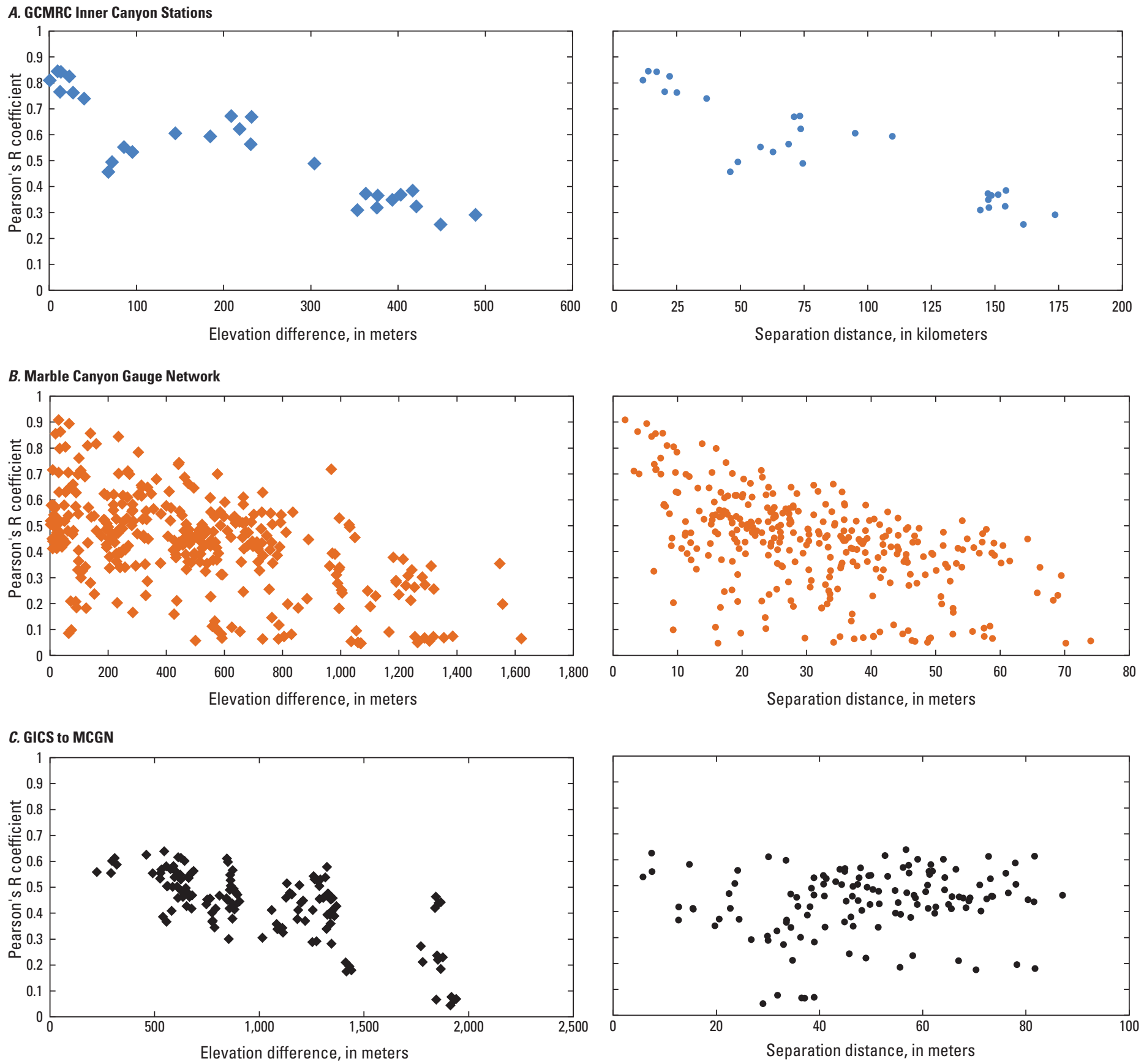

Figure 2. Daily rain correlations between (A) U.S. Geological Survey (USGS) Grand Canyon Monitoring and Research Center (GCMRC) inner canyon stations (GICS) within Grand and Marble Canyons, (B) USGS Marble Canyon Gauge Network (MCGN), and (C) GICS and MCGN, plotted by horizontal separation distance and vertical elevation difference for the period from February 2007 through May 2011. In $(C)$ only the five GICS sites west of National Oceanographic and Atmospheric Administration cooperative observer station (NOAA COOP) Phantom Ranch (upper Grand and Marble Canyons) were used. 
For the river stations, four stations were correlated (correlation coefficient $>0.8$ ) when the distance between stations was less than $14 \mathrm{~km}$ and when the elevation difference was less than $23 \mathrm{~m}$ (fig. 2A). As elevation differences between stations within the river corridor are autocorrelated with distance, separation distance is likely a more useful variable than elevation with which to evaluate daily rainfall correlations among stations along the river. For the rim stations, measurements were correlated at $\mathrm{R}>0.8$ for 10 stations where the distance between stations was less than $16 \mathrm{~km}$, and where the elevation difference was less than $235 \mathrm{~m}$ (fig. $2 B$ ). The elevation difference between these 10 correlated stations and the rest of the uncorrelated measurements was not well defined (fig. $2 B$ ), as the mean correlation value for each elevation difference less than $600 \mathrm{~m}$ (evaluated separately for each meter) was between 0.4 and 0.6. The elevation difference of $235 \mathrm{~m}$ likely provides an estimate of the maximum possible vertical difference for correlation to be present rather than a typical difference. Similarly, separation distances of $16 \mathrm{~km}$ included a large range of correlation values, most of which are below 0.8 , though the frequency of correlation coefficients less than 0.8 decreases with even shorter separation distances. Measurements made at paired inner canyon and rim stations had correlation coefficients $<0.7$ and therefore were not considered to be correlated for practical purposes at any separation distances, horizontal or vertical (fig. $2 C$ ). These results provide guidance for reasonable separation distances at which daily rainfall measurements at stations within the canyon might be used to infer rainfall at other nearby inner canyon locations. These results similarly indicate reasonable separation distances for which rainfall measurements at stations on the rim might be used to infer rainfall at other locations on the rim. These results show that rainfall measurements on the rim are not useful to infer daily rainfall below the rim accurately, and vice versa.
Mean annual rainfall at stations in northern Marble Canyon appears to be lower than at stations in western Grand Canyon, though the dispersion of values around the mean, as shown by the standard error, indicates large variability (for example, particularly in the area around the Little Colorado River; fig. 3). In general, the stations in Marble Canyon receive a larger contribution of annual rainfall during the warm season, and the Grand Canyon stations receive more annual rainfall during the cool season (fig. 3). However, the proportion of cool to warm season rainfall appears to be approximately equal at the upstream (northern) station in Marble Canyon (Lees Ferry) and the stations near the transition between Marble and Grand Canyon (fig. 3). Although the relatively small number and large separation distances between GICS locations prevent the assumption of a continuous pattern in rainfall, the consistently significant difference in cool and warm season means at the four westernmost stations in Grand Canyon during the threeyear assessment period might suggest that differences exist between the eastern and western portions of the Grand Canyon region along the river corridor, though confirmation of this concept cannot be accomplished with these spatially discontinuous monitoring datasets (fig. 3).

Annual rainfall among all of the stations is greatest on the Kaibab Plateau (fig. $4 A$ ), the highest orographic feature along the canyon rim by over 1,000 m. Rainfall on the Kaibab Plateau is relatively evenly distributed between warm and cool seasons for most of the stations, with the exception of those at highest elevations at the head of North Canyon (MCGN North-1; appendix 2 and at the southwesternmost station, COOP Bright Angel Ranger Station. These two gauges are located towards the southern end of the Kaibab Plateau and receive considerably more rainfall annually $(>100 \mathrm{~mm})$ than any other station location in the area. Annual rainfall among the rim stations is typically less at lower elevation stations (fig. $4 A$ ). For river stations, site

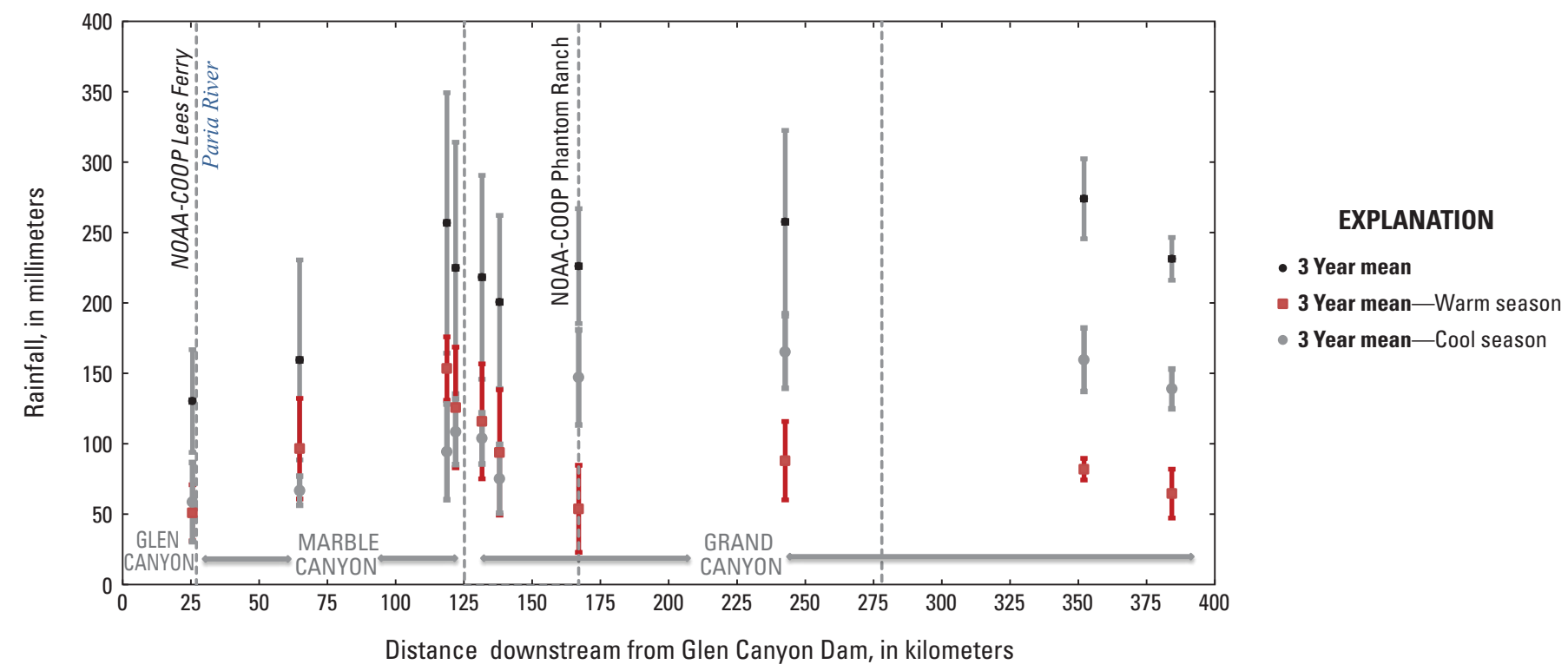

Figure 3. Spatial distribution of rainfall for 2008-10 recorded by U.S. Geological Survey Grand Canyon Monitoring and Research Center (GCMRC) inner canyon stations (GICS) and the Lees Ferry and Phantom Ranch National Oceanographic and Atmospheric Administration cooperative observer stations (NOAA COOP). Error bars represent the standard error of the mean. Approximate extents of Glen, Marble, and Grand Canyons are provided for reference. 
elevation itself does not appear to be a significant influence on variability in rain accumulation (fig. $4 A$ ). However, there does appear to be a significant positive relation between variability in rain accumulation at river stations as a function of the elevation of nearby topographic features on the rim (fig. 4A). The stations associated with the highest regional landform, the Kaibab Plateau, particularly east of the plateau, had high but variable rainfall. For most of the lower elevation rim stations and river stations in Marble Canyon and eastern Grand Canyon, the ratio of cool to warm season rainfall was either near unity or skewed toward greater warm season rainfall (fig. $4 B$ ). Although within the same range of annual rainfall means as the rim and river stations in Marble Canyon, stations in western Grand Canyon had a greater percentage of annual rainfall during the cool season, though less exaggerated than the Bright Angel Rangers Station (fig. 4A). The transition in the seasonal distribution of rainfall for the stations within the canyon, as well as the variability in rainfall accumulation for stations around the Little Colorado River suggests that the Kaibab Plateau could influence the geographic distribution of rainfall, possibly by affecting regional atmospheric flow, though
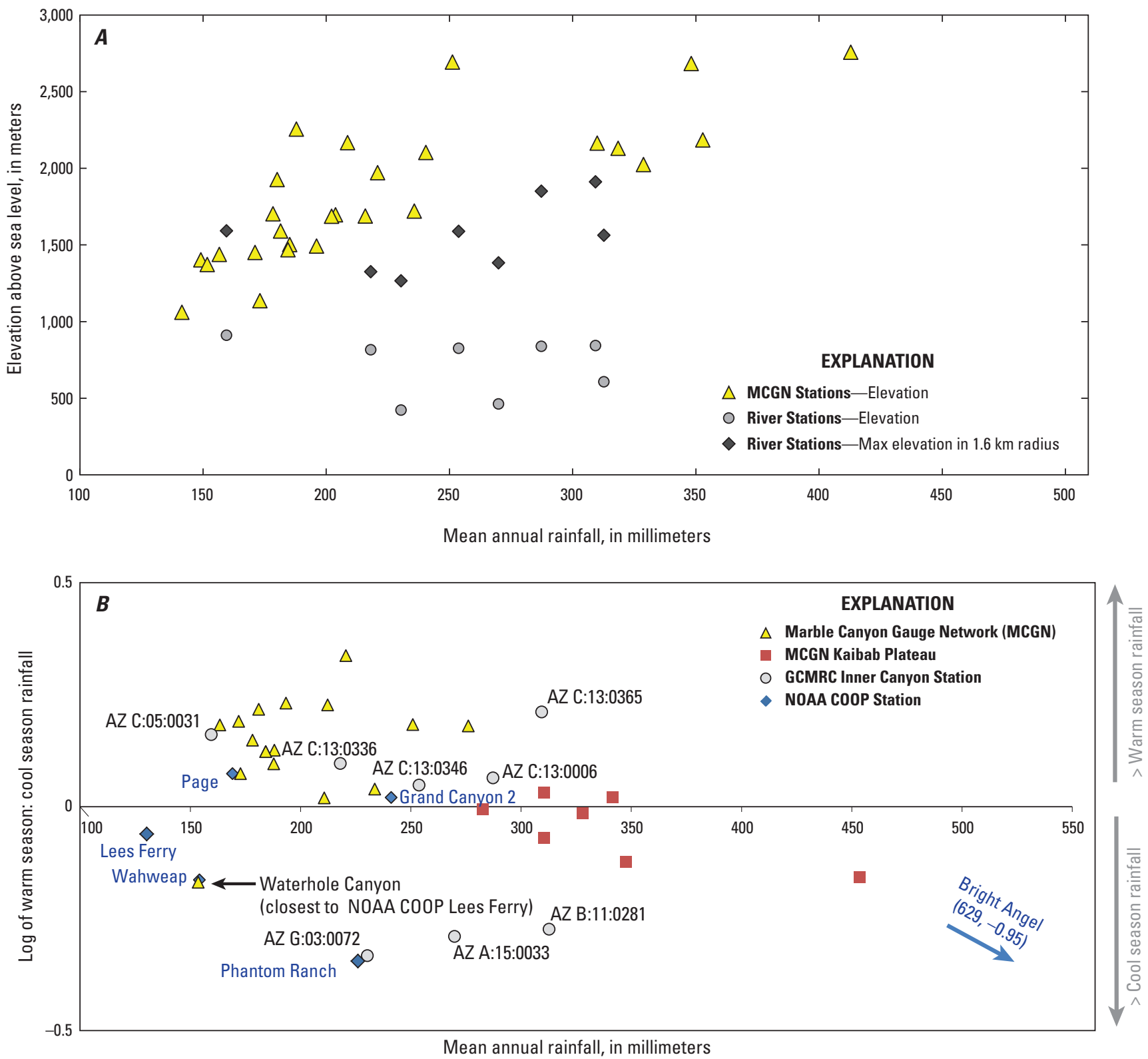

Figure 4. Relation of 2008-10 station rainfall by elevation and seasonal rainfall regime. $(A)$ Plot of the mean annual rainfall by elevation at MCGN stations (yellow triangles), and at the combined record of observations from the river corridor at GICS and NOAA COOP stations Phantom Ranch and Lees Ferry (grey circles). River station mean annual rainfall was additionally plotted by maximum elevation within a $1.6 \mathrm{~km}$ (1 mile) radius of a station, a proxy for rim elevation and canyon wall slope (black diamonds). (B) Plot of the log ratio of mean warm season to cool season rainfall as a function of mean annual rainfall for Marble Canyon Gauge Network (MCGN) stations and by U.S. Geological Survey (USGS) Grand Canyon Monitoring and Research Center (GCMRC) inner canyon stations (GICS) and National Oceanographic and Atmospheric Administration cooperative observer stations (NOAA COOP). 
more spatially continuous data than the monitoring datasets used in this study would be needed both above and within Grand Canyon to adequately investigate this hypothesis.

Analysis of rainfall intensity within Marble and Grand Canyons confirmed previous studies (Hereford and Webb, 1992; Hereford and others, 2014) that found rainfall intensity during the warm season can exceed that during the cool season by an order of magnitude (fig. $5 \mathrm{~A}$ ). Mean rainfall intensity during the warm season was not significantly different between the eastern and western stations in the canyon during the 3 years of observation. Conversely, the western stations in Grand Canyon receive more intense rainfall than the northern Marble Canyon station during the cool season. In general, the annual maximum daily rain intensity occurred during the warm season, with the
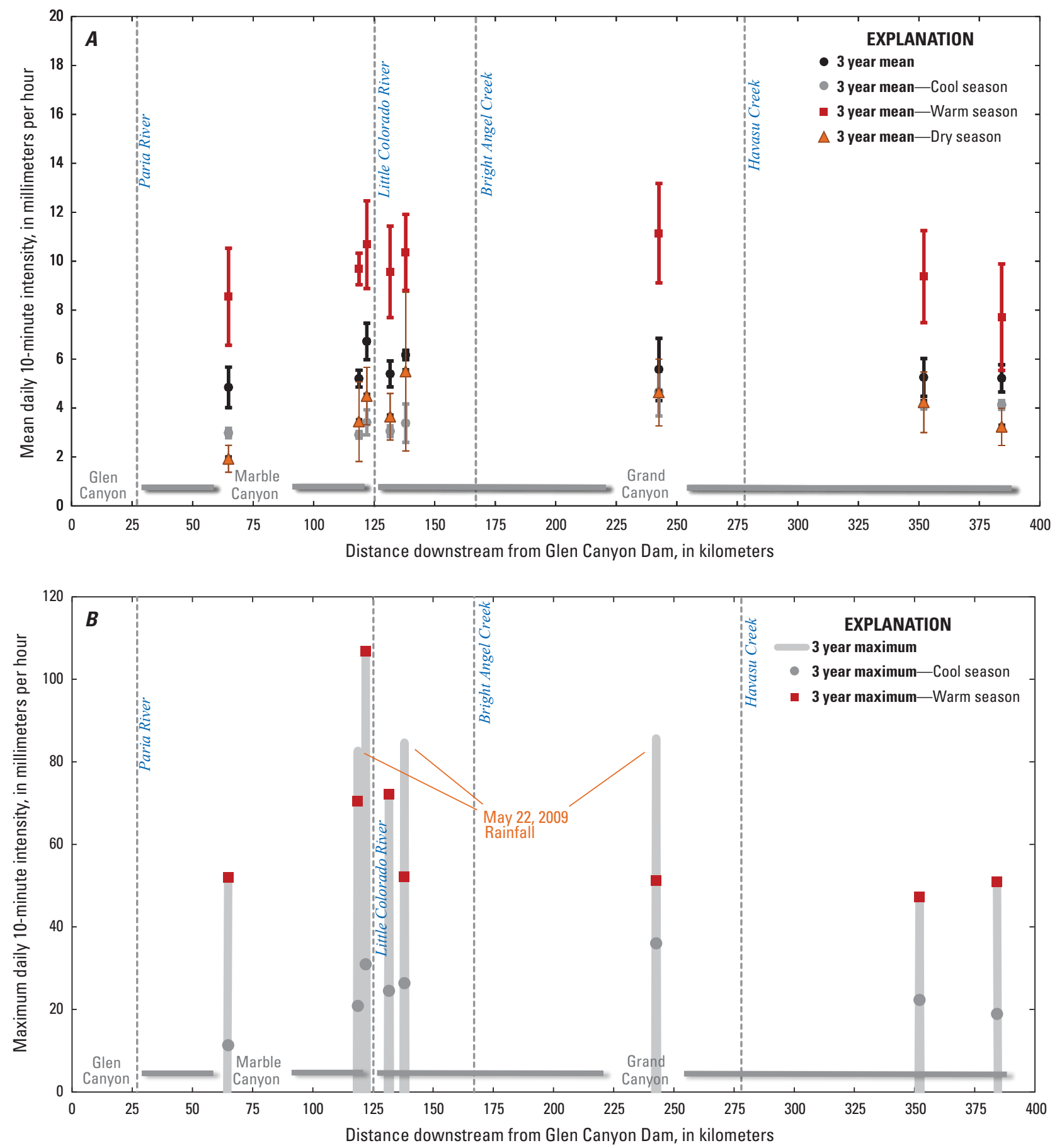

Figure 5. Summary of daily 10-minute rain intensity at U.S. Geological Survey Grand Canyon Monitoring and Research Center inner canyon stations during 2008-10. (A) Annual and seasonal mean daily 10-minute intensity by downstream distance from Glen Canyon Dam. Error bars represent the standard error of the mean. $(B)$ Annual and seasonal maximum daily 10-minute intensity by distance from Glen Canyon Dam. Most of the highest intensity values were measured during the warm season; however, high intensities were measured during the 2009 dry season at three locations. 
notable exception of a single dry-season storm in which three GICS sites recorded the highest 3-year daily rainfall intensity values on May 22, 2009 (fig. 5B).

During the 3-year observation period, the 99 and 99.9 percentile values calculated from all rain events recorded at GICS stations were $16.5 \mathrm{~mm}$ per day and $42.8 \mathrm{~mm}$ per day, respectively (table 1). These values are higher than the 99 and 99.9 percentile daily rainfall record at the NOAA COOP stations Phantom Ranch and Lees Ferry during the same period (table 1), and were more similar to the 99 and 99.9 percentile values determined from the long-term record (1950-2012) of maximum daily rainfall between these two NOAA COOP stations (table 1). Median $I_{10}$ values for rainfall above the 99 and 99.9 percentile of daily rainfall were $32.4 \mathrm{~mm}$ per hour $\left(99-I_{10}\right)$ and $45.3 \mathrm{~mm}$ per hour $\left(999-I_{10}\right)$, respectively. Both the 99 and 99.9 percentile of daily rainfall and median $I_{10}$ values are within Renard and others (1997) criteria for rainfall potential to induce erosion (in other words, cumulative rainfall $>12.7 \mathrm{~mm}$, or event maximum 15 -minute rain intensity $>24.1 \mathrm{~mm}$ per hour).

At least one storm occurred at each GICS location that exceeded the 99-I $I_{10}$ threshold; and the two stations immediately upstream of the Little Colorado River in southern Marble Canyon (stations AZ C:13:0365 and AZ C:13:0006) averaged two or more annually (fig. 6A). During 2008-10, storms that exceeded the 999-I $I_{10}$ threshold were recorded only at GICS sites in southern Marble Canyon and eastern Grand Canyon (stations AZ C:13:0365, AZ C:13:0006, AZ C:13:0336, AZ C:13:0346, and AZ B:11:0281, fig. $6 B$ ). The addition of the incomplete 2007 records indicate that all stations recorded at least one daily rainfall event above the 99.9 percentile with intensity above $999-I_{10}$. The station immediately upstream of the Little Colorado River (AZ C:13:0006) was the only location at which the $999-I_{10}$ threshold exceedance averaged once a year (fig. $6 B$ ). Recurrence of daily rainfall exceeding the 999- $I_{10}$ threshold for the other stations could not be adequately assessed with the available monitoring data.

\section{Long-Term Rainfall Depth Variability}

Although there is some similarity in rainfall pattern, long-term annual rainfall at the NOAA COOP stations in Marble and Grand Canyons is considerably less than the Grand Canyon regional record aggregated from 28 stations identified by Hereford and others (2014) as making up the Grand Canyon station group (fig. 7A; appendix 1). Seasonal rainfall also exhibited similar temporal patterns compared to the 28-station aggregate dataset, though warm-season rain at Phantom Ranch and Lees Ferry appears to show more frequent deviations from the regional trend (fig. 7B,C). Rainfall was typically higher at Phantom Ranch compared to Lees Ferry with the exception of some drought years when Lees Ferry received more rainfall during the warm season (fig. 7). Rainfall patterns within the region have been previously demonstrated to be related to the El Niño Southern Oscillation (ENSO) and Pacific Decadal Oscillation (PDO), with dry periods corresponding to negative PDO and La Niña, and wet periods corresponding to positive PDO and El Niño phases (Hereford and Webb, 1992).

Table 1. Summary of daily rainfall percentile at U.S. Geological Survey Grand Canyon Monitoring and Research Center inner canyon stations (GICS) and National Oceanographic and Atmospheric Administration Cooperative Observer (NOAA COOP) river stations.

[Daily rainfall percentiles for the $\mathrm{GICS}_{3 y,}$, NOAA COOP $3 y$, , and NOAA COOP full $_{\text {w }}$ were calculated from all daily rainfall observations during the period assessed. $\mathrm{NOAA} \mathrm{COOP}_{\max }$ daily rainfall percentiles were calculated from the maximum daily rainfall recorded at either COOP station. The median of daily maximum 10-minute intensities $\left(I_{10}\right)$ was calculated from all observations above the 99 and 99.9 percentile recorded at GICS stations during the period of assessment. $\mathrm{Mm} / \mathrm{d}$, millimeters per day; $\mathrm{mm} / \mathrm{hr}$, millimeters per hour; $\mathrm{N} / \mathrm{A}$, not applicable]

\begin{tabular}{|c|c|c|c|c|c|}
\hline River corridor stations & Period assessed & $\begin{array}{c}99 \text { percentile } \\
(\mathrm{mm} / \mathrm{d})\end{array}$ & $\begin{array}{c}99-I_{10} \\
(\mathrm{~mm} / \mathrm{hr})\end{array}$ & $\begin{array}{l}99.9 \text { percentile } \\
(\mathrm{mm} / \mathrm{d})\end{array}$ & $\begin{array}{l}999-I_{10} \\
(\mathrm{~mm} / \mathrm{hr})\end{array}$ \\
\hline GICS $_{3 y r}$ & $2008-10$ & 16.5 & 32.4 & 42.8 & 45.3 \\
\hline $\mathrm{NOAA} \mathrm{COOP}_{3 y r}$ & $2008-10$ & 14.0 & $\mathrm{~N} / \mathrm{A}$ & 27.9 & N/A \\
\hline $\mathrm{NOAA} \mathrm{COOP}_{\text {full }}$ & 1950-2012 & 11.9 & N/A & 30.5 & N/A \\
\hline $\mathrm{NOAA} \mathrm{COOP}_{\max }$ & 1950-2012 & 15.2 & N/A & 37.3 & N/A \\
\hline
\end{tabular}



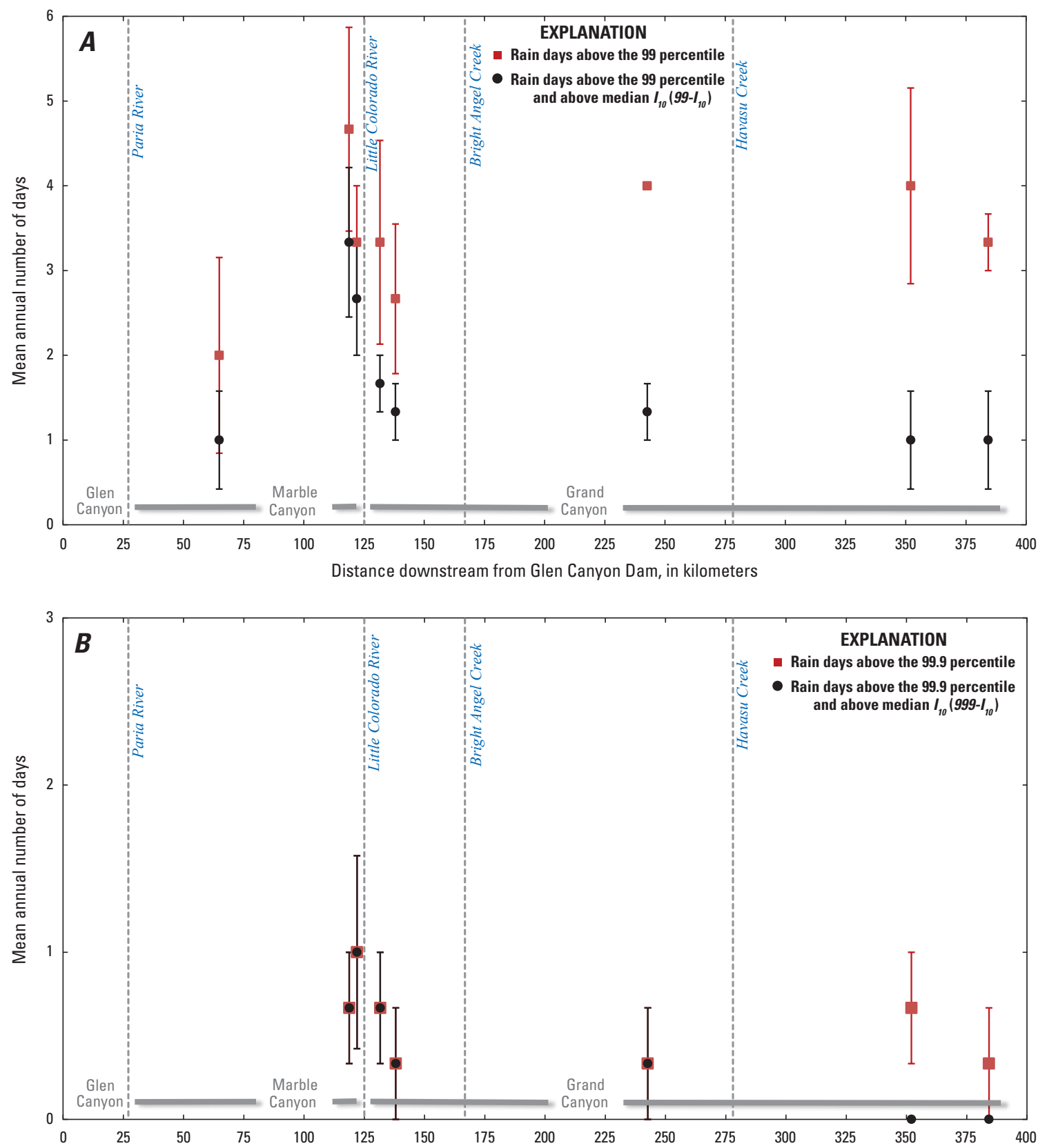

Figure 6. Mean annual number of days that were above daily rainfall percentile and associated median 10-minute intensities $\left(I_{10}\right)$ for the 2008-10 assessment period at U.S. Geological Survey Grand Canyon Monitoring and Research Center inner canyon stations. $(A)$ Mean frequency of days above the 99 percentile daily rainfall $(16.5 \mathrm{~mm} / \mathrm{d})$ and median $I_{10}\left(32.4 \mathrm{~mm} / \mathrm{hr}\right.$ ) (termed the $99-I_{10}$ threshold). (B) Mean frequency of days above the 99.9 percentile daily rainfall $(42.8 \mathrm{~mm} / \mathrm{d})$ and median $I_{10}\left(45.3 \mathrm{~mm} / \mathrm{hr}\right.$ ) (termed the $999-I_{10}$ threshold). Error bars represent standard error of the mean $\left(99-I_{10}\right)$. 

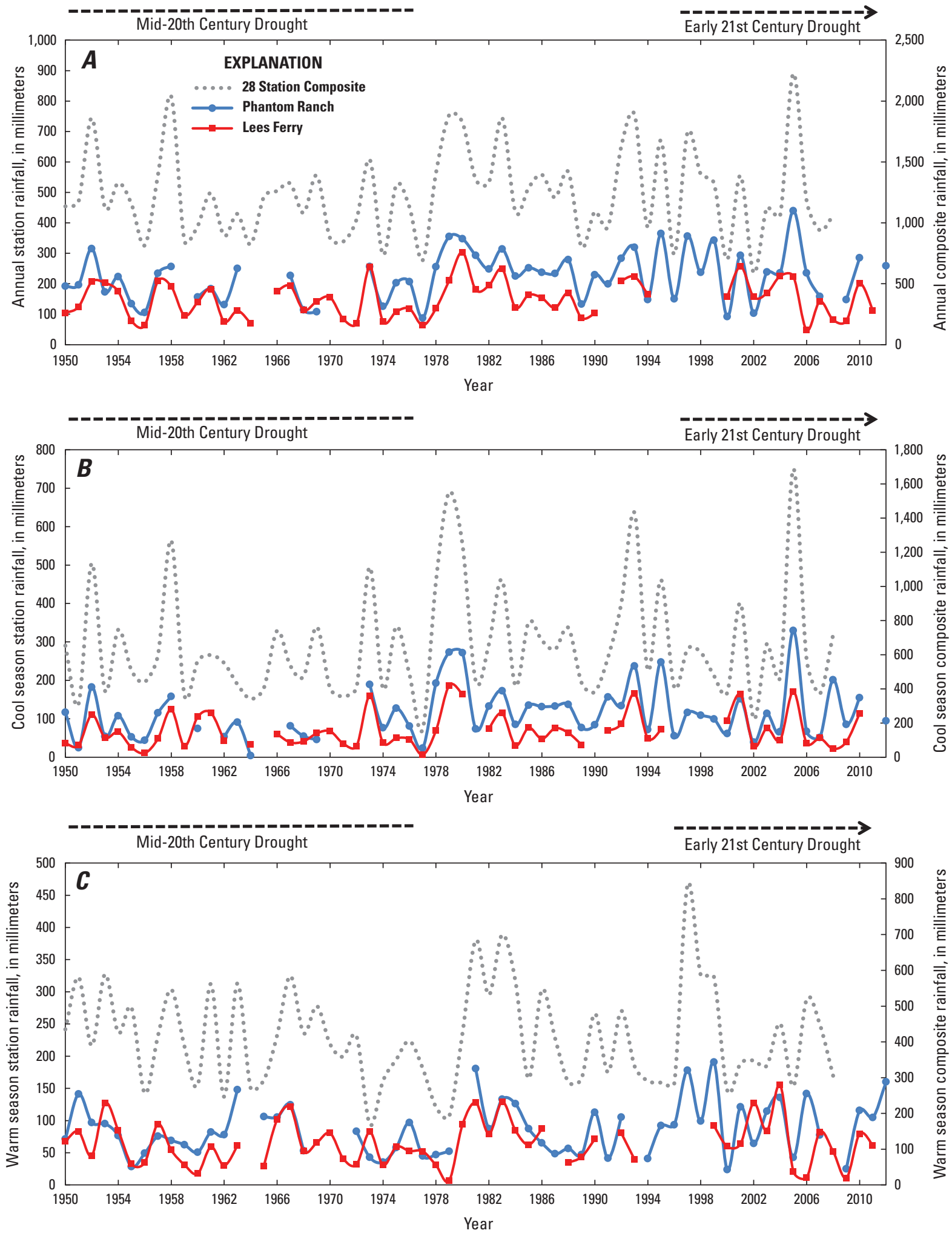

Figure 7. (A) Annual, $(B)$ cool-season, and (C) warm-season rainfall for 1950-2012 at National Oceanographic and Atmospheric Administration cooperative observer stations (NOAA COOP) Phantom Ranch and Lees Ferry. Only years with $\geq 80$ percent complete records were included ( $>292$ daily records per year). The mean of 28 NOAA COOP stations (not including Phantom Ranch or Lees Ferry) on the southern Colorado Plateau is provided for regional reference. Drought designations were adapted from Hereford and others (2014). 
The regional mean of the 28 NOAA COOP stations is significantly correlated with observed rainfall along the river; correlations are weak for the warm season, however, though stronger for the cool season (table 2). The Phantom Ranch NOAA COOP station is more strongly correlated than Lees Ferry is to the regional (28-station) composite (table 2). The Phantom Ranch and Lees Ferry stations are relatively weakly correlated to each other in all seasons.

\section{Long-Term Rainfall Intensity Variability}

Regression models to predict daily maximum intensity from daily rainfall are presented in table 3 , with the graphical results provided in appendix 3. An additional set of models is included in table $3\left(\right.$ GICS $\left._{\text {corr }}\right)$ to provide the appropriate coefficients for predicting rainfall variables measured with the tipping-bucket gauges, as opposed to the piezoelectric sensor $\left(G I C S_{\text {raw }}\right)$ used at all GICS locations. The model relations show that among the three geographic groups of stations, the GICS sites experience the most intense episodes of rainfall given the same daily rain depth (fig. 8; appendix 3). The highest-elevation gauges, MCGN-Kaibab, experience the lowest intensity given the same rain depth (fig. 8).

Based on the AIC results in table 4, the depth-intensity relationships for each geographic group and season (table 3) are almost as efficient at estimating maximum daily rainfall intensity at any individual station as the equation specific to that station. This is expected for the river stations, given the statistically similar mean intensities between most of the measurement stations (fig. 5). For the river stations, all GICS $S_{\text {raw }}$ and most of the $G I C S_{\text {corr }}$ seasonal equation estimates were within five $\triangle \mathrm{AIC}$ units of the individual equations (table 4; appendix 2). Predicted intensities using the two rim station equations were significantly different from those predicted by the individual GICS equations and are therefore not considered useful in estimating daily intensity within the canyon (table 4; appendix 2).

Table 2. Results of linear regression of annual and seasonal rainfall between Phantom Ranch and Lees Ferry National Oceanographic and Atmospheric Administration Cooperative Observer (NOAA COOP) stations, and the regional mean of 28 NOAA COOP stations, for the years from 1950 to 2008.

[Calculated P-values indicate all relationships exceed the 99 percent level of significance]

\begin{tabular}{lcccccccccc}
\hline \multirow{2}{*}{ Time period } & \multicolumn{3}{c}{ Phantom Ranch: Regional } & \multicolumn{3}{c}{ Lee's Ferry: Regional } & \multicolumn{3}{c}{ Phantom Ranch: Lee's Ferry } \\
\cline { 2 - 12 } & Slope & $\mathbf{R}^{2}$ & P-value & Slope & $\mathbf{R}^{2}$ & P-value & Slope & $\mathbf{R}^{\mathbf{2}}$ & P-value $^{2}$ \\
\hline Annual & 0.186 & 0.73 & $<0.00001$ & 0.112 & 0.47 & $<0.00001$ & 0.886 & 0.45 & $<0.00001$ \\
Cool season & 0.188 & 0.83 & $<0.00001$ & 0.112 & 0.70 & $<0.00001$ & 1.200 & 0.58 & $<0.00001$ \\
Warm season & 0.196 & 0.49 & $<0.00001$ & 0.151 & 0.32 & 0.00002 & 0.565 & 0.25 & 0.00041 \\
\hline
\end{tabular}

Table 3. Regression results for log-transformed, daily rainfall depth (predictor) and daily maximum 10 -minute intensity $\left(I_{10} ;\right.$ response) variables for U.S. Geological Survey Grand Canyon Monitoring and Research Center inner canyon stations (GICS) and the Marble Canyon Gauge Network (MCGN).

[GICS $_{\text {corr }}$ provides coefficients for comparison of GICS $_{\text {raw }}$ data acquired with a piezoelectric sensor to rainfall records acquired with tipping-bucket gauges (MCGN) using the adjustment factor of Basara and others (2009)]

\begin{tabular}{|c|c|c|c|c|c|c|c|c|}
\hline $\begin{array}{c}\text { Multistation } \\
\text { geographic group }\end{array}$ & Season & Slope & $\begin{array}{l}\text { Standard } \\
\text { error }\end{array}$ & Intercept & $\begin{array}{l}\text { Standard } \\
\text { error }\end{array}$ & $\mathbf{R}^{2}$ & $\begin{array}{c}\text { Residual } \\
\text { standard } \\
\text { error }\end{array}$ & P-value \\
\hline \multirow{3}{*}{ GICSraw } & Cool & 0.6835 & 0.0061 & 0.6029 & 0.0126 & 0.9 & 0.466 & $<0.00001$ \\
\hline & Dry & 0.7382 & 0.0078 & 0.7677 & 0.0181 & 0.909 & 0.477 & $<0.00001$ \\
\hline & Warm & 0.8562 & 0.0059 & 1.1523 & 0.0131 & 0.952 & 0.421 & $<0.00001$ \\
\hline \multirow{3}{*}{ GICScorr } & Cool & 0.6835 & 0.0061 & 0.5076 & 0.0131 & 0.9 & 0.466 & $<0.00001$ \\
\hline & Dry & 0.7382 & 0.0078 & 0.6888 & 0.0193 & 0.909 & 0.477 & $<0.00001$ \\
\hline & Warm & 0.8562 & 0.0059 & 1.1089 & 0.0136 & 0.952 & 0.421 & $<0.00001$ \\
\hline \multirow{3}{*}{ MCGN } & Cool & 0.37 & 0.0098 & 0.7446 & 0.0129 & 0.545 & 0.425 & $<0.00001$ \\
\hline & Dry & 0.4859 & 0.0156 & 0.9327 & 0.0206 & 0.689 & 0.426 & $<0.00001$ \\
\hline & Warm & 0.6691 & 0.0204 & 1.1844 & 0.013 & 0.737 & 0.52 & $<0.00001$ \\
\hline \multirow{3}{*}{ MCGN-Kaibab } & Cool & 0.3479 & 0.0137 & 0.6187 & 0.0171 & 0.461 & 0.4 & $<0.00001$ \\
\hline & Dry & 0.4317 & 0.0158 & 0.8521 & 0.0208 & 0.654 & 0.394 & $<0.00001$ \\
\hline & Warm & 0.6218 & 0.0147 & 1.0967 & 0.023 & 0.737 & 0.507 & $<0.00001$ \\
\hline
\end{tabular}


Figure 8. Depth-intensity relations based on the (A) cool-, $(B)$ dry-, and $(C)$ warm-season equations presented in table 2 for U.S. Geological Survey Grand Canyon Monitoring and Research Center inner canyon station (GICS) and the Marble Canyon Gauge Network (MCGN). The MCGN-Kaibab and GICS corrected plots represent high elevation gauges on the Kaibab Plateau and predicted GICS piezoelectric sensor values corrected for compatibility with tipping bucket rain gauges, respectively. Appendix 2 provides a plot of all seasonal data used to define the depth-intensity relations within $A-C$.

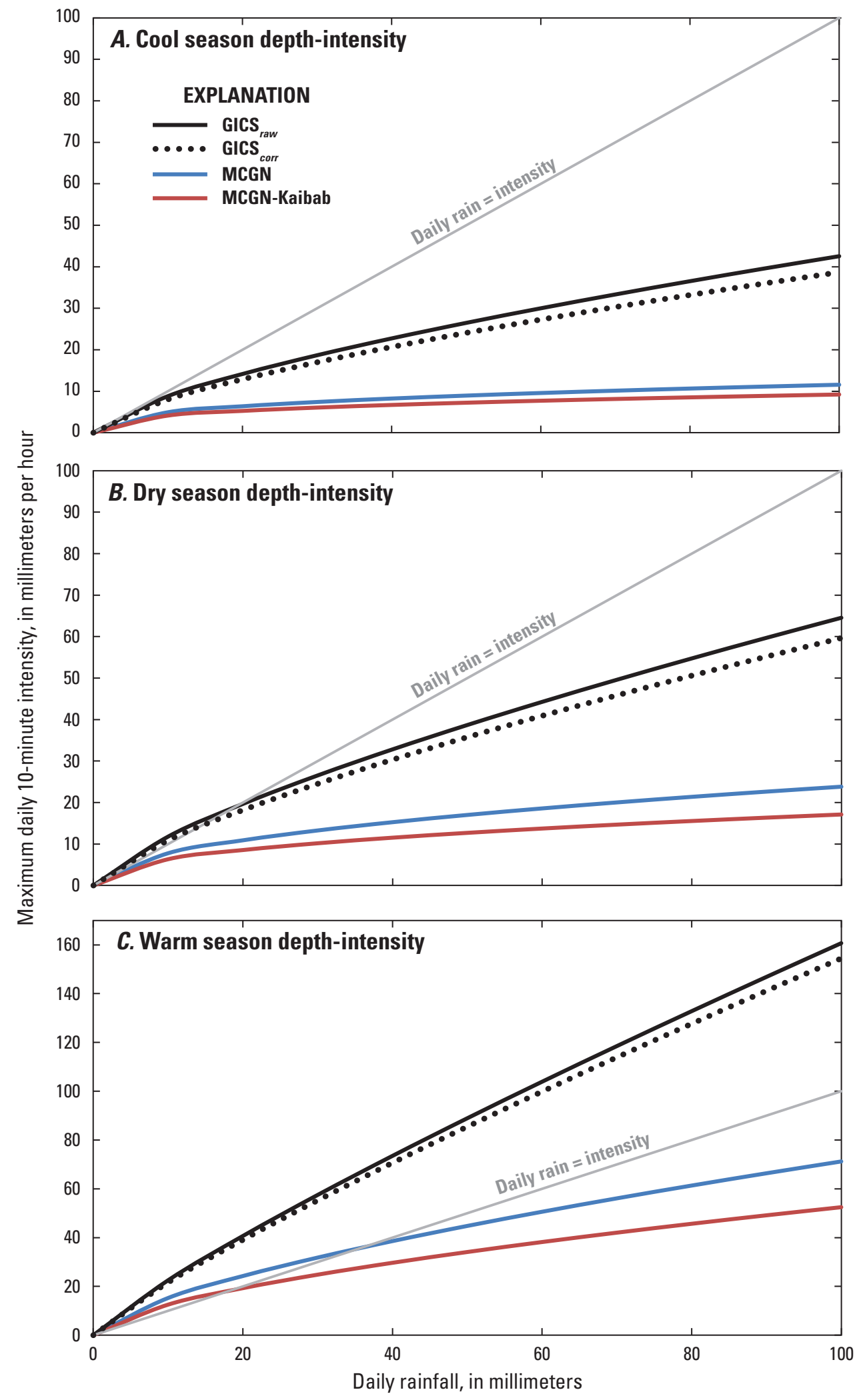


Table 4. Results of an Akaike Information Criterion (AIC) evaluation of modeled daily 10-minute intensity from individual stations and three multi-station geographic group regression equations.

[Geographic groups included in the table were U.S. Geological Survey Grand Canyon Monitoring and Research Center inner canyon stations without a factor correction for compatibility with tipping-bucket gauges (GICSraw), GICS with a factor correction (GICScorr), Marble Canyon Gauge Network lower elevation sites (MCGN), and MCGN higher elevation stations on the Kaibab Plateau (MCGN-Kaibab). The table shows the number of individual stations in each season and group (columns) by $\triangle \mathrm{AIC}$ (rows). Where groups contain individual station $\Delta \mathrm{AIC}$ values $>5$, group totals are less than the total number of stations. N/A indicates that group $\triangle \mathrm{AIC}$ values were not evaluated. Calculated AIC values are presented in appendix 2]

\begin{tabular}{|c|c|c|c|c|c|c|}
\hline $\begin{array}{c}\text { Multi-station } \\
\text { geographic group }\end{array}$ & AIC category & $\begin{array}{l}\text { Individual } \\
\text { stations }\end{array}$ & $\begin{array}{l}\text { Group } 1 \text { - } \\
\text { GICSraw }\end{array}$ & $\begin{array}{l}\text { Group } 1 \text { - } \\
\text { GICScorr }\end{array}$ & $\begin{array}{l}\text { Group } 2 \text { - } \\
\text { MCGN }\end{array}$ & $\begin{array}{c}\text { Group } 3 \text { - } \\
\text { MCGN-Kaibab }\end{array}$ \\
\hline \multicolumn{7}{|c|}{ Cool season } \\
\hline \multirow{4}{*}{ GICSraw: 5 Total } & Lowest AIC & 5 & 0 & N/A & 0 & 0 \\
\hline & Statistically similar (<2 AIC) & 0 & 4 & N/A & 0 & 0 \\
\hline & Similar $(<5$ AIC) & 0 & 1 & $\mathrm{~N} / \mathrm{A}$ & 0 & 0 \\
\hline & Group total & 5 & 5 & N/A & 0 & 0 \\
\hline \multirow{4}{*}{ GICScorr: 5 Total } & Lowest AIC & 5 & 0 & 0 & 0 & 0 \\
\hline & Statistically similar (<2 AIC) & 0 & 2 & 4 & 0 & 0 \\
\hline & Similar $(<5$ AIC $)$ & 0 & 1 & 1 & 0 & 0 \\
\hline & Group total & 5 & 3 & 5 & 0 & 0 \\
\hline \multirow{4}{*}{$\begin{array}{l}\text { MCGN Stations: } \\
11 \text { Total }\end{array}$} & Lowest AIC & 11 & 0 & 0 & 0 & 0 \\
\hline & Statistically similar (<2 AIC) & 0 & 0 & 0 & 2 & 1 \\
\hline & Similar $(<5$ AIC) & 0 & 0 & 0 & 5 & 1 \\
\hline & Group total & 11 & 0 & 0 & 7 & 2 \\
\hline \multirow{4}{*}{$\begin{array}{l}\text { MCGN-Kaibab } \\
\text { Stations: } 5 \text { Total }\end{array}$} & Lowest AIC & 5 & 0 & 0 & 0 & 0 \\
\hline & Statistically similar (<2 AIC) & 0 & 0 & 0 & 0 & 1 \\
\hline & Similar $(<5$ AIC $)$ & 0 & 0 & 0 & 0 & 4 \\
\hline & Group total & 5 & 0 & 0 & 0 & 5 \\
\hline \multicolumn{7}{|c|}{ Dry season } \\
\hline \multirow{4}{*}{ GICSraw: 5 Total } & Lowest AIC & 5 & 0 & $\mathrm{~N} / \mathrm{A}$ & 0 & 0 \\
\hline & Statistically similar (<2 AIC) & 0 & 4 & $\mathrm{~N} / \mathrm{A}$ & 0 & 0 \\
\hline & Similar (<5 AIC) & 0 & 1 & $\mathrm{~N} / \mathrm{A}$ & 0 & 0 \\
\hline & Group total & 5 & 5 & N/A & 0 & 0 \\
\hline \multirow{4}{*}{ GICScorr: 5 Total } & Lowest AIC & 5 & 0 & 0 & 0 & 0 \\
\hline & Statistically similar (<2 AIC) & 0 & 3 & 2 & 0 & 0 \\
\hline & Similar (<5 AIC) & 0 & 1 & 1 & 0 & 0 \\
\hline & Group total & 5 & 4 & 2 & 0 & 0 \\
\hline \multirow{4}{*}{$\begin{array}{l}\text { MCGN Stations: } \\
11 \text { Total }\end{array}$} & Lowest AIC & 4 & 0 & 0 & 7 & 0 \\
\hline & Statistically similar (<2 AIC) & 4 & 0 & 0 & 1 & 1 \\
\hline & Similar $(<5$ AIC) & 3 & 0 & 0 & 0 & 0 \\
\hline & Group total & 11 & 0 & 0 & 8 & 1 \\
\hline
\end{tabular}


Table 4. Results of an Akaike Information Criterion (AIC) evaluation of modeled daily 10-minute intensity from individual stations and three multi-station geographic group regression equations.-Continued

\begin{tabular}{|c|c|c|c|c|c|c|}
\hline $\begin{array}{c}\text { Multi-station } \\
\text { geographic group }\end{array}$ & AIC category & $\begin{array}{l}\text { Individual } \\
\text { stations }\end{array}$ & $\begin{array}{l}\text { Group } 1 \text { - } \\
\text { GICSraw }\end{array}$ & $\begin{array}{l}\text { Group } 1 \text { - } \\
\text { GICScorr }\end{array}$ & $\begin{array}{c}\text { Group } 2 \text { - } \\
\text { MCGN }\end{array}$ & $\begin{array}{c}\text { Group } 3 \text { - } \\
\text { MCGN-Kaibab }\end{array}$ \\
\hline \multirow{4}{*}{$\begin{array}{l}\text { MCGN-Kaibab } \\
\text { Stations: } 5 \text { Total }\end{array}$} & Lowest AIC & 0 & 0 & 0 & 0 & 5 \\
\hline & Statistically similar $(<2$ AIC $)$ & 0 & 0 & 0 & 0 & 0 \\
\hline & Similar $(<5$ AIC $)$ & 0 & 0 & 0 & 0 & 0 \\
\hline & Group total & 0 & 0 & 0 & 0 & 5 \\
\hline \multicolumn{7}{|c|}{ Warm season } \\
\hline \multirow{4}{*}{ GICSraw: 5 Total } & Lowest AIC & 5 & 0 & N/A & 0 & 0 \\
\hline & Statistically similar $(<2$ AIC) & 0 & 3 & N/A & 0 & 0 \\
\hline & Similar $(<5$ AIC $)$ & 0 & 2 & N/A & 0 & 0 \\
\hline & Group total & 5 & 5 & N/A & 0 & 0 \\
\hline \multirow{4}{*}{ GICScorr: 5 Total } & Lowest AIC & 5 & 0 & 0 & 0 & 0 \\
\hline & Statistically similar $(<2$ AIC) & 0 & 4 & 4 & 0 & 0 \\
\hline & Similar (<5 AIC) & 0 & 1 & 1 & 0 & 0 \\
\hline & Group total & 5 & 5 & 5 & 0 & 0 \\
\hline \multirow{4}{*}{$\begin{array}{l}\text { MCGN Stations: } \\
11 \text { Total }\end{array}$} & Lowest AIC & 11 & 0 & 0 & 0 & 0 \\
\hline & Statistically similar $(<2$ AIC) & 0 & 0 & 0 & 9 & 0 \\
\hline & Similar $(<5$ AIC $)$ & 0 & 0 & 0 & 1 & 0 \\
\hline & Group total & 11 & 0 & 0 & 10 & 0 \\
\hline \multirow{4}{*}{$\begin{array}{l}\text { MCGN-Kaibab } \\
\text { Stations: } 5 \text { Total }\end{array}$} & Lowest AIC & 5 & 0 & 0 & 0 & 0 \\
\hline & Statistically similar $(<2$ AIC) & 0 & 0 & 0 & 0 & 5 \\
\hline & Similar $(<5$ AIC $)$ & 0 & 0 & 0 & 0 & 0 \\
\hline & Group total & 5 & 0 & 0 & 0 & 5 \\
\hline
\end{tabular}

\section{Validation of Seasonal Depth-Intensity Models}

The GICS seasonal equations provide the best method for estimating the maximum daily rain intensity at river stations where daily rainfall depth, but not intensity, is available. To evaluate the utility of the GICS equations, rain intensity was estimated at six GICS sites, three of which were not in operation during the calibration period, for data collected during 2013-14 and compared with measured values (fig. 9). The calibration period was observed to have received above average rainfall within some parts of the Colorado Plateau (R. Hereford, U.S. Geological Survey, written commun., July 6, 2015). The relation between the actual and predicted intensities is significant and strong (fig. 9). The highest residual value $(53.8 \mathrm{~mm})$ was during the dry-season, a three month period when rainfall is infrequent, but during which strong storms can periodically occur.

Days with intensities exceeding $99-I_{10}$ and $999-I_{10}$ thresholds were reasonably well predicted by the seasonal models. For recorded daily rainfall above the 99 percentile during the validation period, there were 17 days measured and 20 days predicted to have $I_{10}$ exceeding the 99- $I_{10}$ threshold $(>32.4 \mathrm{~mm} / \mathrm{hr}$ ). All of the 17 recorded exceedances were correctly identified with three predicted $I_{10}$ values for recorded rainfall below the $99-I_{10}$ threshold. For recorded daily rainfall above the 99.9 percentile, there was only one $I_{10}$ exceedance of the $999-I_{10}$ threshold observed. The exceedance was correctly predicted by the model. 


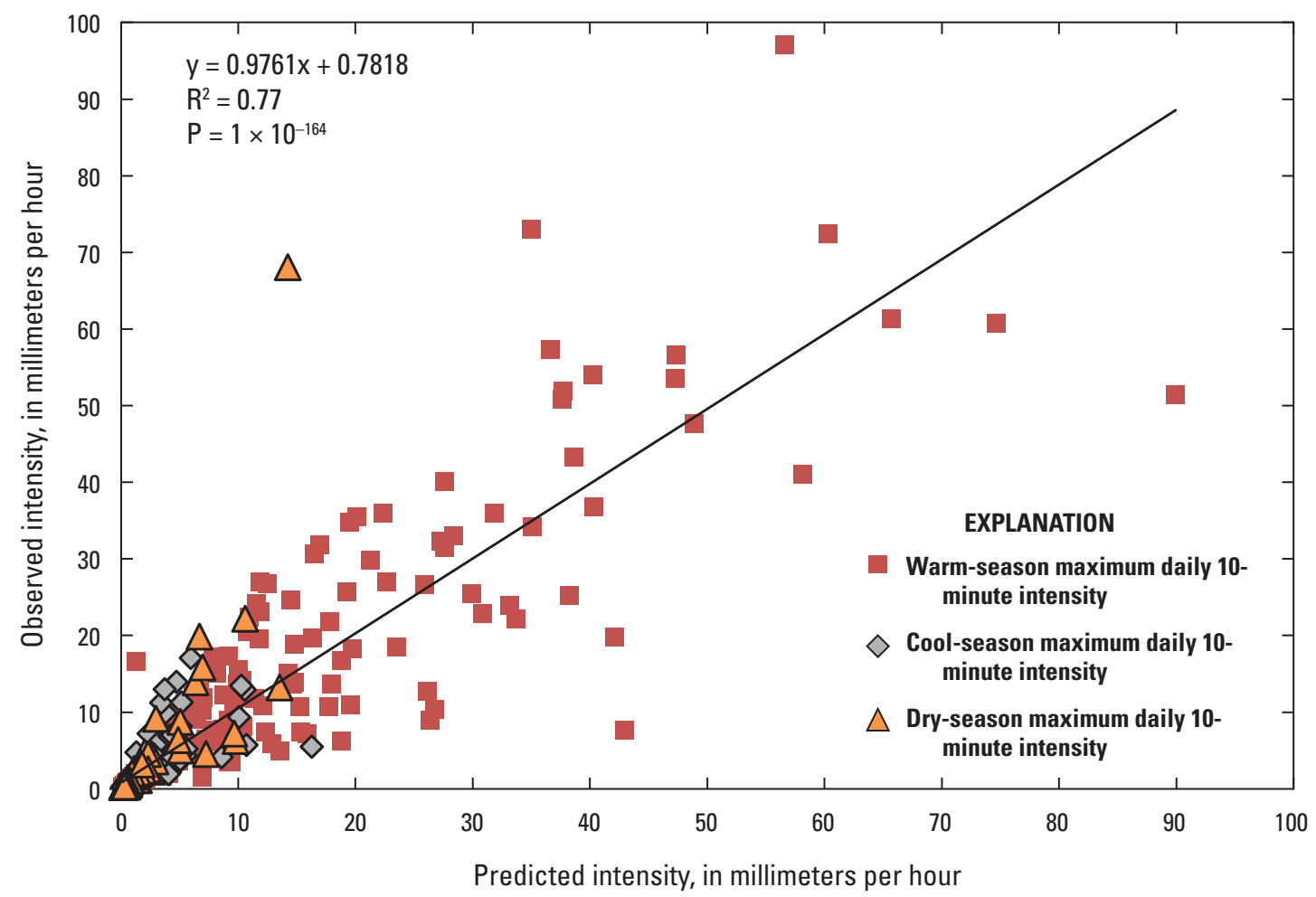

Figure 9. Comparison of predicted and observed maximum daily 10-minute intensities for data collected from November 2013 to September 2014. The U.S. Geological Survey Grand Canyon Monitoring and Research Center inner canyon stations seasonal equations were used to predict intensity. Statistical values were calculated using all days with recorded rainfall.

\section{Estimation of Rainfall Intensity at NOAA COOP Stations}

Long-term rainfall intensity appears to have been somewhat greater at Phantom Ranch compared to Lees Ferry, based on the relative number of total days above the $99-I_{10}$ and $999-I_{10}$ thresholds from 1950-2012 (fig. 10A,B). Between 1950 and 2012, nine days were predicted to have exceeded the $99-I_{10}$ threshold at both COOP stations (rain events at both stations within 24 to 48 hours) and 104 days exceeded the 99-I threshold at either the Phantom Ranch (66 days) or Lees Ferry (36 days) station (fig. 10) for a total of 113 threshold rainfall events during the 62-year period.

Consistent with the results of the short-term rainfall analysis, analysis of long-term data shows that daily rainfall amounts $>16.5 \mathrm{~mm} / \mathrm{d}$ with predicted maximum 10 -minute intensities $>32.4 \mathrm{~mm} / \mathrm{hr}\left(99-I_{10}\right)$ within the canyon occurs, on average, at least once a year for both NOAA COOP stations. The most frequent predicted annual exceedances of the $99-I_{10}$ threshold were during 1981 and $1999(\mathrm{n}=6)$, with 1967, 2003, and 2012 having one less event $(\mathrm{n}=5$; fig. 10C). For daily rainfall amounts $>42.8 \mathrm{~mm} / \mathrm{d}$ with maximum 10 -minute intensities $>45.3 \mathrm{~mm} / \mathrm{hr}\left(999-I_{10}\right)$, only six events, four at Phantom Ranch and two at Lees Ferry, were predicted for 1950-2012. This suggests a typical recurrence interval around 10 years, though most of these predicted exceedances have occurred after 1980 (fig. 10C). The two predicted exceedances of the $999-I_{10}$ in the mid-1980s were both at Phantom Ranch, the one predicted exceedance in the mid-1990s was at Lees Ferry, and the two predicted exceedances in the mid-2000s were distributed between both stations (fig. 10C). 

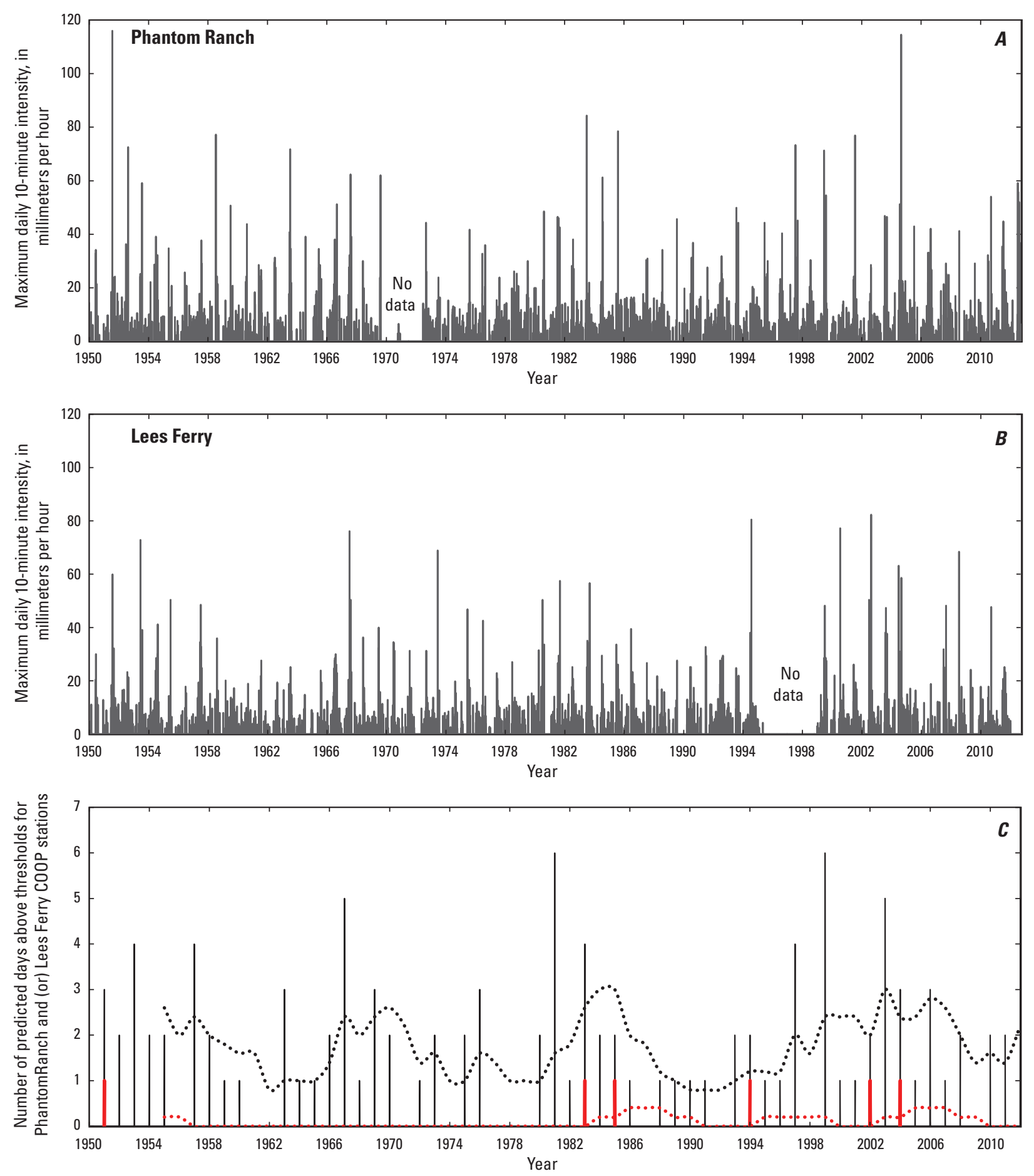

EXPLANATION

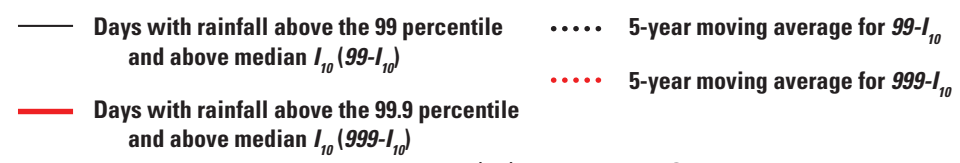

Figure 10. Predicted maximum daily 10 -minute rainfall intensity $\left(I_{10}\right)$ at National Oceanographic and Atmospheric Administration cooperative observer stations (NOAA COOP) (A) Phantom Ranch and (B) Lees Ferry estimated using the U.S. Geological Survey Grand Canyon Monitoring and Research Center inner canyon stations (GICS) seasonal equations. (C) Predicted number of days per year from both NOAA COOP stations with daily rainfall exceeding the $99(16.5 \mathrm{~mm} / \mathrm{d})$ and $99.9(42.8 \mathrm{~mm} / \mathrm{d})$ percentile that were above the median $I_{10}$ values $\left(99-I_{10}>32.4 \mathrm{~mm} / \mathrm{hr} ; 999-I_{10}>45.3 \mathrm{~mm} / \mathrm{hr}\right)$. The number of annual predicted days when the thresholds were exceeded was determined as threshold rainfall events recorded at one or at both stations within 48 hours. No threshold rainfall events were predicted for consecutive days. 


\section{Discussion}

The timing and magnitude (depth) of rainfall measured at monitoring stations in Marble and Grand Canyons show some variability between eastern and western stations, and between high- and low-elevation stations at annual and seasonal scales. Stations in the eastern part of the study area (in Marble Canyon to Lees Ferry) typically receive either near-equal rainfall among seasons or a larger proportion of annual rainfall during the warm season (July 1-October 7), whereas the westernmost stations in the study area (in central and western Grand Canyon) receive relatively more rainfall during the cool season (October 8-March 31). Between these stations and the eastern two sections of the study area is the Kaibab Plateau, the highest elevation landform above the north rim of the canyon. Stations on the Kaibab Plateau receive the most annual rainfall among all monitoring stations. Interestingly, some of the most variable rainfall observed at river stations occurred at stations along the base of the Kaibab Plateau. The most intense rainfall among the monitoring stations occurs at low-elevation sites within the river corridor. Rainfall intensity is greatest during the warm season for all river stations.

Although mean rainfall intensity during the warm season does not vary significantly between river stations, the two stations in southern Marble Canyon, below the east edge of the Kaibab Plateau, receive more-frequent high-intensity storms. The Phantom Ranch and Lees Ferry NOAA COOP data are consistent with the east-west trends observed for the GCMRC inner canyon (GICS) stations. Annual and seasonal rainfall is typically higher at Phantom Ranch than at Lees Ferry, with more frequent high intensity storms with potential to generate runoff. Below, we discuss in more detail the rainfall variability observed in the short-term record and the long-term NOAA COOP record since 1950.

\section{Rainfall Spatial Distribution}

The strongest correlations between river stations are between the four stations in southern Marble Canyon and eastern Grand Canyon. Physiographically, these are locations where the river corridor widens, the north rim is to the west and is significantly higher than the south rim, and the canyon is oriented north-south. Interestingly, Phantom Ranch is $22.3 \mathrm{~km}$ downstream from GICS AZ C:13:0346 in eastern Grand Canyon, the shortest separation distance between a GICS and NOAA COOP, yet correlation between these stations is low. In general, daily rain correlations between NOAA COOP stations and MCGN or GICS stations are weak $(\mathrm{R} \leq 0.5)$, no matter the separation distance. This may be caused by differences in measurement apparatus and procedure. However, it is also likely related to differences in canyon orientation and physiography. For example, the best correlation $(\mathrm{R}=0.54)$ between Phantom Ranch and a GICS station was with AZ B:11:0281, which is $45.9 \mathrm{~km}$ downstream from Phantom Ranch. These stations are separated by a greater distance than that between Phantom Ranch and AZ C:13:0346, but they are both located in regions of the canyon that are similarly oriented (northwest-southeast), located to the west of the Kaibab Plateau, and in a more narrow section of the canyon than the stations east of the Inner Gorge. Overall, our results suggest that although spatial proximity of stations is important for determining the extent to which daily rainfall is similar between inner canyon locations, the canyon and rim physiography, and the function of the Kaibab Plateau as an orographic division between weather systems in Marble (especially southern Marble Canyon) and Grand Canyons are likely useful considerations for understanding rainfall distribution.

\section{Distribution of Rainfall Intensity}

The monitoring stations along the river experience more intense rainfall than do the monitoring stations above the canyon rims. This spatial difference in intensity might be related to temperature differences and associated upward circulation, factors proposed to affect the frequency of high intensity rain events (Karl and Knight, 1998; Kunkel and others, 2012; Mondal and Mujumdar, 2015). Based on these ideas, we propose that future investigations into differential rain intensity within the region focus on warmer temperatures along the river, differential canyon wall heating, and the subsequent higher saturation vapor pressure and greater water-holding capacity of the air, which may contribute to greater rainfall intensity along the river compared to above the canyon rims.

We have demonstrated how daily maximum rainfall intensity $\left(I_{10}\right)$ can be inferred from daily rainfall depth using relations that vary by season and location. Along the river corridor, stations located below the east side of the Kaibab Plateau (southern Marble Canyon) typically receive more warm-season rainfall than other station locations in the canyon, and receive more frequent high-intensity storms that can generate runoff. The National Weather Service Next Generation Radar (NEXRAD) time series for August 8, 2008, shown in figure 11, illustrates an example of how a warm-season storm can build over the Kaibab and Paria Plateaus and track east across Marble Canyon. There were several such storms between 2008 and 2010 that produced high-intensity warm-season rain events. In figure 11, the highest radar reflectivity values (red and yellow in the map) indicate areas with predicted high rainfall depth and intensity. These areas tend to be located above especially high regions of the canyon rim, including the Kaibab Plateau, and track across southern Marble Canyon, suggesting especially high rainfall within this part of the canyon. During the storm shown in figure 11, rainfall recorded at AZ C:13:0006 was substantial (30.7 mm with 10-minute maximum intensity of $41.4 \mathrm{~mm} / \mathrm{hr}$ on September 22, 2007; $51.6 \mathrm{~mm}$ with 10-minute maximum intensity of $64.5 \mathrm{~mm} / \mathrm{hr}$ on August 8, 2008), Phantom Ranch was minimal (4.1 and $0 \mathrm{~mm}$ for those dates, respectively) and rainfall recorded at Lees Ferry varied between substantial (24.4 mm on September 22, 2007) and none ( $0 \mathrm{~mm}$ on August 8, 2008). 


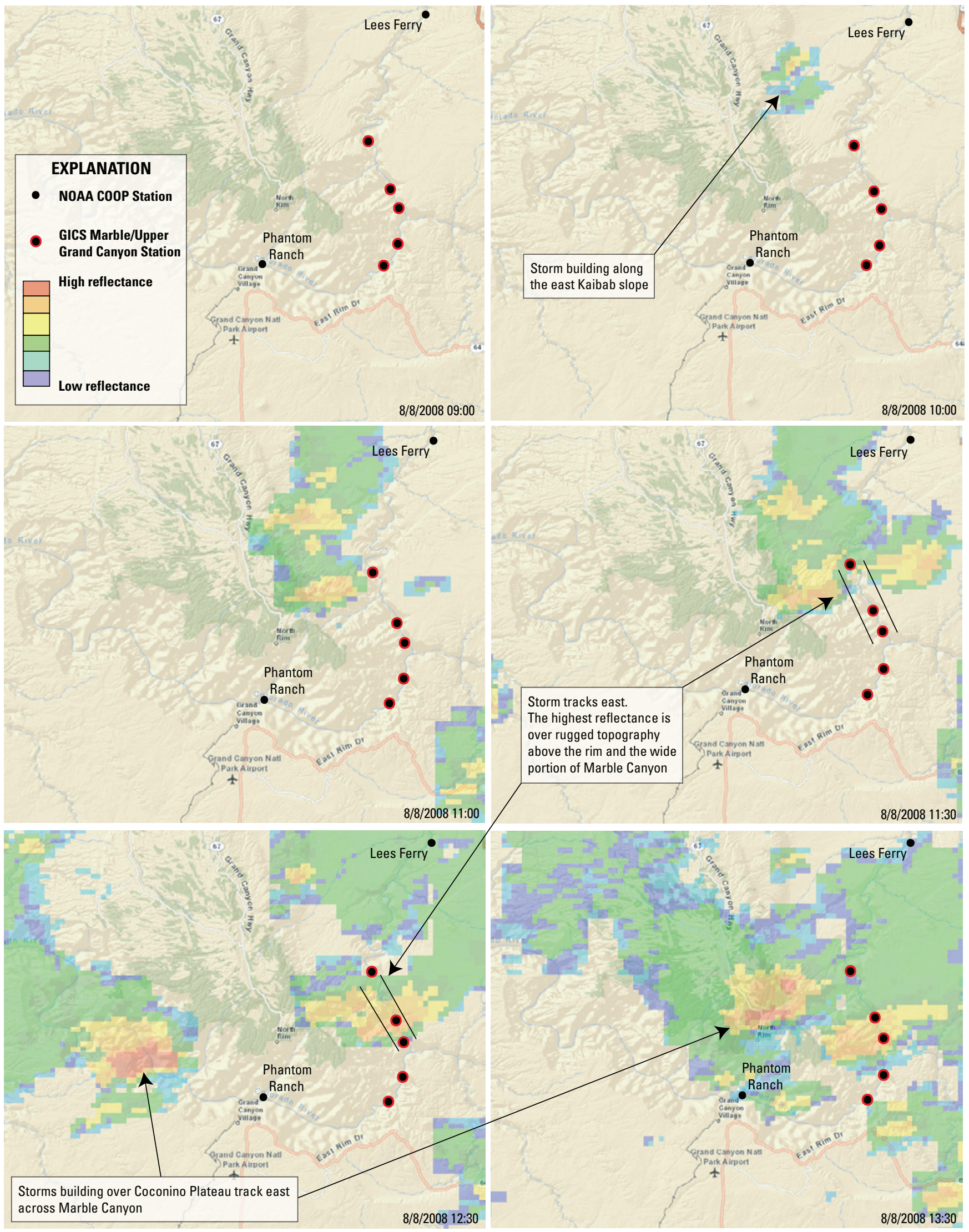

Figure 11. National Weather Service time series of composite radar coverage over Marble and Grand Canyons on August 8, 2008. Data adapted from the National Climate Data Center's Climate Data Online interactive map (http://gis.ncdc.noaa.gov/map/viewer). Radar reflectivity represents the maximum range composite (derived datset) for stations Cedar City, Utah; Las Vegas, Nevada; and Flagstaff, Arizona. 
Another useful and common observation from the radar data is the development of warm-season storms that build to the west and south of Phantom Ranch over the Coconino Plateau and track east. Recorded rainfall during this scenario is typically higher at Phantom Ranch (for example, $20.3 \mathrm{~mm}$ with an estimated 10-minute maximum intensity of $41.2 \mathrm{~mm} / \mathrm{hr}$ on August 16, 2008) and GICS B:11:0281 (22.3 mm with 10-minute maximum intensity of $38.5 \mathrm{~mm} / \mathrm{hr}$ on August 16, 2008), the inner-canyon location with the highest recorded intensity in central Grand Canyon, than at the GICS stations in southern Marble Canyon (AZ C:13:0006 received $8.9 \mathrm{~mm}$ with 10-minute maximum intensity of $10.8 \mathrm{~mm} / \mathrm{hr}$ on August 16, 2008). Lees Ferry $(0 \mathrm{~mm}$ on August 16,2008$)$ frequently does not receive significant amounts of rainfall during this type of warm-season storm. Collectively, these observations suggest that rainfall depth and intensity can be very different between stations in Grand Canyon and Marble Canyon depending on spatial differences in storm-cell origin, though these examples provide only a few potential causes for differential rainfall. Additional future analysis of data that are more spatially and temporally continuous than the monitoring station data, such as the NEXRAD data set, will likely identify other potential patterns that can be used in refining our understanding of daily or multiday spatial relations.

Differences between warm-season rainfall accumulation at Phantom Ranch (62 year mean of $87.2 \mathrm{~mm}$ ) and Lees Ferry (62 year mean of $64.7 \mathrm{~mm}$ ) may represent broad differences in frequency of recurring warm season storm patterns and subsequent high intensity rainfall events in Grand and northern Marble Canyons. However, the longer-term Lees Ferry record is an imperfect analog from which to infer long-term rain activity in Marble Canyon because of the inconsistency with which Lees Ferry receives rainfall from storms that track over Marble Canyon. We believe this is a result of the local topography. Central Marble Canyon is narrow (1-2 km) and deep $(0.5-1 \mathrm{~km})$ with the broad, low (1,475 m elevation) House Rock Valley to the west and Eminence Break (1,500 m elevation) to the east above the rim. Lees Ferry, located within the wider $(5 \mathrm{~km})$ valley confluence of the Paria and Colorado Rivers, is framed by the Paria Plateau (2,200 m elevation) to the west and the Kaibito Plateau (1,950 m elevation) to east, both of which have the potential to affect atmospheric flow and could be a cause of differences in rainfall between northern and central Marble Canyon. Nonetheless, Pederson and others (2006) observed during the summer of 2002 that frequent high-intensity storms at Lees Ferry were indicative of more erosive conditions on the east side of the Kaibab Plateau, in Marble Canyon. In the absence of direct long-term measurements from within Marble Canyon, the long-term record from Lees Ferry likely provides the only (though imperfect) data for extrapolating long-term conditions in this segment of the river corridor.

\section{Runoff Potential}

Understanding regional and local rainfall patterns is an integral part of understanding the drivers of landscape change along the Colorado River in the Grand Canyon region, and particularly for understanding the potential for overland flow to damage archaeological sites within erodible sedimentary deposits (Hereford and others 1993, 2014). For the high-intensity, short-duration storms investigated in this study, the potential for rainfall intensity to exceed infiltration is the most probable cause of runoff and runoff erosion within unconsolidated sediment along the Colorado River in Marble and Grand Canyons. While this may be a typical cause of runoff originating in the unconsolidated substrate of the river corridor, concentrated overland flow from rainfall on impermeable surfaces (in other words, bedrock and talus) can greatly increase potential for runoff erosion both above and within the river corridor, especially where topography and slope are advantageous for flow (Pederson and others, 2006). We reviewed over 100 photographs between April 2013 and May 2014 from remote stationary cameras positioned around two of the GICS sites (fig. 12), and identified locations of erosion where rills formed only after high intensity rainfall events. These observations appear to corroborate the usefulness of the 99- $I_{10}$ and $999-I_{10}$ thresholds. In the time series for Phantom Ranch (fig. 12C), exceedances of the $99-I_{10}$ threshold (daily rainfall $>16.5 \mathrm{~mm} / \mathrm{d} ; I_{10}>32.4 \mathrm{~mm} / \mathrm{hr}$ ) appear to correspond with high-intensity rain events recorded approximately $50 \mathrm{~km}$ to the northwest at AZ B:10:0225 (fig. 12B). Two of these events, recorded in late August and early September 2013, were also observed in Marble Canyon at AZ C:05:0031 (fig. 12A). This suggests that although the Phantom Ranch NOAA COOP station is a useful analog for rainfall within Grand Canyon west of Kaibab Plateau (eastern and central Grand Canyon), it may also capture some high intensity storms observed in Marble Canyon. In general, predicted rainfall intensity at Phantom Ranch is less than that measured at GICS stations, but the frequency for exceedance of the $99-I_{10}$ threshold is similar between these stations. However, neither the Phantom Ranch nor the Lees Ferry COOP station captured all rain days recorded at the GICS locations east of the Kaibab Plateau in Marble Canyon.

Hereford and others $(1993,2014)$ documented a 17-year period from 1978 to 1995 (termed the Wet Period) with multiple consecutive years of above-average rainfall. They suggested that the beginning of this period, from 1978 to 1985, incurred substantial runoff erosion and development of gullies within Marble and Grand Canyons (Hereford and others, 1993, 2014). On average, there were at least 20 more annual days of rainfall during the Wet Period than during the preceding period of record and the 5-year moving average of annual days exceeding the $99-I_{10}$ threshold shows a marked peak during this period (fig. $10 C$ ). Analysis of our long-term predictions of rainfall intensity suggests that the average frequency of days with rainfall sufficient to generate runoff is comparable between the Wet Period and the preceding years assessed from 1950 to 1977 (fig. 10), though the annual concentration of these high intensity rainfall days is not comparable. More than 22 percent of all daily exceedances of the minimum intensity threshold during the Wet Period occurred during 1981, and more than 60 percent occurred between 1980 and 1985 , which might indicate that these specific years during the Wet Period included anomalously frequent high-intensity storms (fig. 10C). 

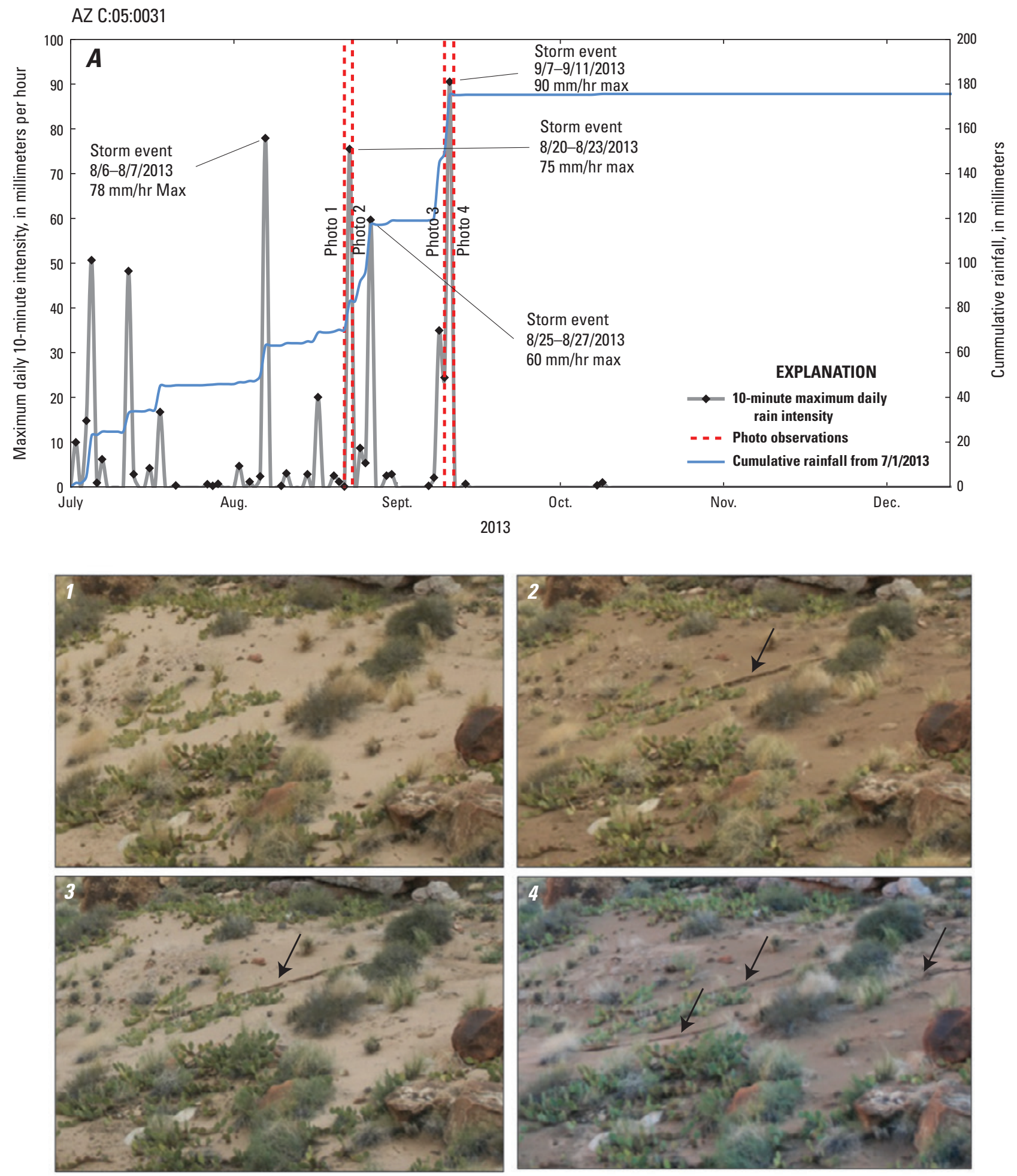

Figure 12. Time series plot showing cumulative rainfall and rainfall intensity during the summer of 2013 for U.S. Geological Survey Grand Canyon Monitoring and Research Center inner canyon stations (A) AZ C:05:0031 and (B) AZ B:10:0225. Photographs from nearby stationary cameras show observed surface changes (black arrows). (C) Cumulative rainfall and estimated rainfall intensity during the summer of 2013 for National Oceanographic and Atmospheric Administration cooperative observer station Phantom Ranch. 

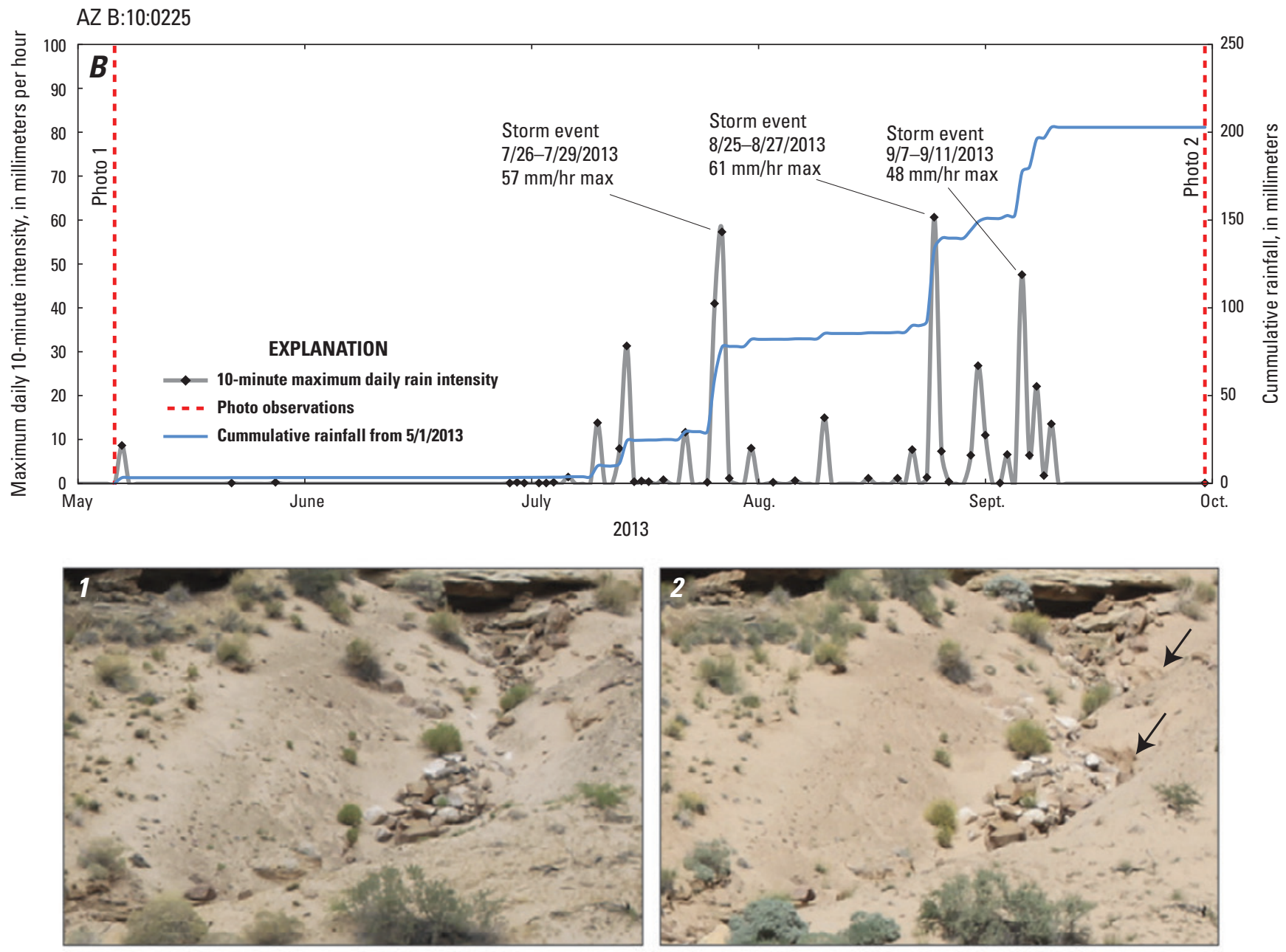

Phantom Ranch

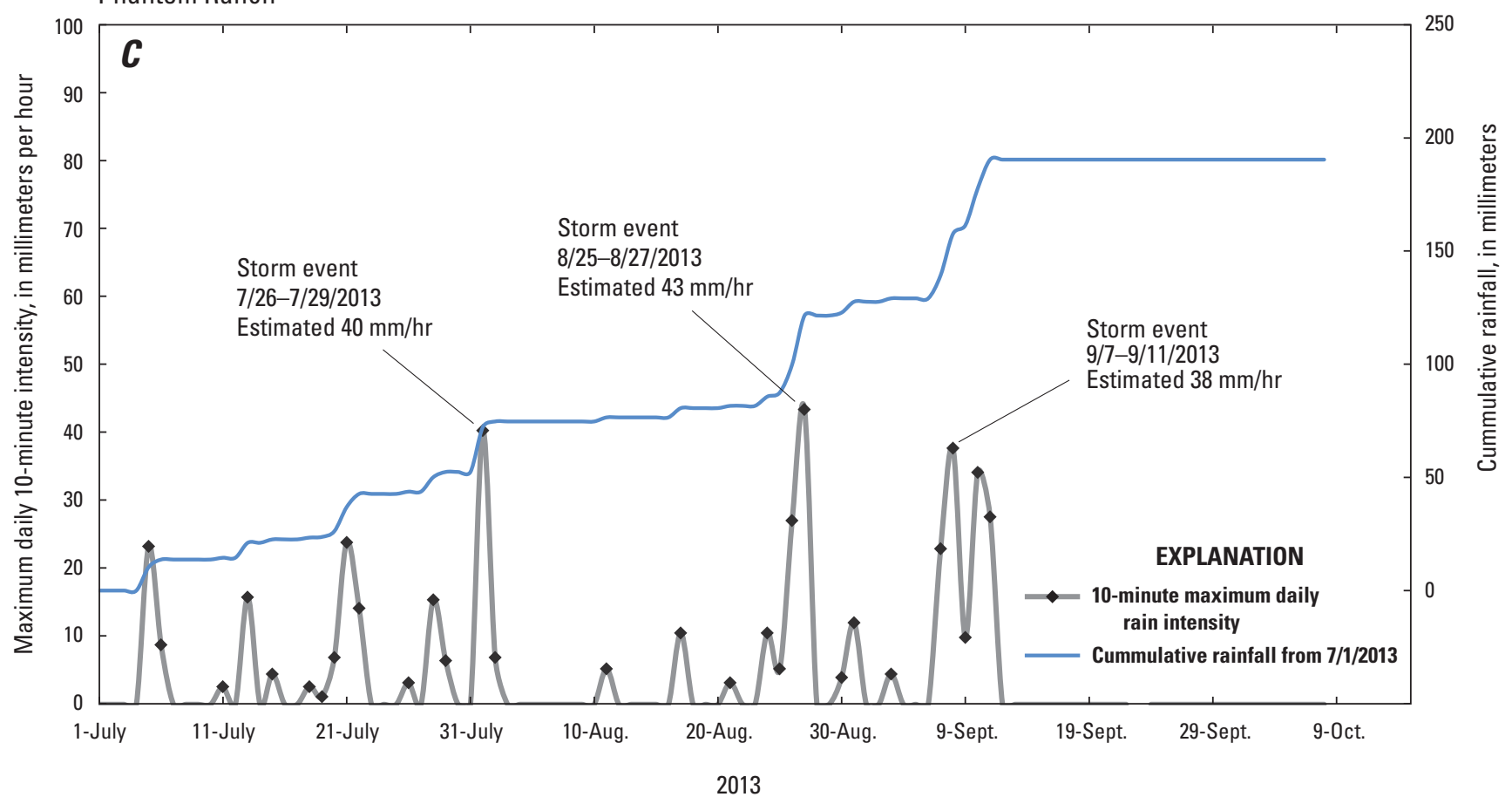

Figure 12.-Continued 
Since 1996, drought conditions have been present in the Grand Canyon region (termed the Early 21st Century Drought; Hereford and others, 2014). Interestingly, even though rainfall totals have been below average during most of this drought phase for the region (13 percent decrease in annual mean rainfall for the 28-station regional composite), our long-term predictions of rainfall intensity at Phantom Ranch and Lees Ferry suggest that the frequency of storms with potential to generate runoff has remained relatively high along the river since the onset of the present drought, with at least three years $(1999,2003$, and 2012) predicted to have similar frequency of high intensity storms (days predicted to exceed the $99-I_{10}$ threshold) as 1981 ( $>4$ storms per year). These results seem to fit the observed national pattern of increases in extreme summer rainfall events (Karl and Knight, 1998; Groisman and others, 2001; Kunkel and others, 2012). While annual rainfall decreased with the transition to drought after 1995 (Hereford and others, 2014), average annual and warm-season rainfall from 1996-2012 (238.2 mm annual mean at Phantom Ranch) is more similar to the Wet Period (262.1 mm annual mean at Phantom Ranch) than to earlier periods of drought (in other words, 1950-77; the end of the Mid-20th Century Drought; $184.7 \mathrm{~mm}$ annual mean at Phantom Ranch). Since 1995, years with low annual rainfall (below the 62-year mean) have occurred owing to an overall decrease in cool-season rainfall (as opposed to decreases in dry- or warm-season rainfall) when rainfall intensity is typically less sufficient to generate runoff caused by exceedance of infiltration. Warm-season rainfall, when storm intensity is typically strongest (Hereford and Webb, 1992; Hereford and others, 2014), within the Grand Canyon region (28-station regional mean; appendix 1) has been increasing since the beginning of the assessment period, from an annual mean rainfall of $396.1 \mathrm{~mm}$ in the 20th Century Drought (1950-77), to $405.6 \mathrm{~mm}$ during the Wet Period (1978-95), to $440.4 \mathrm{~mm}$ during the Early 21st Century Drought (1996-2008). If rainfall intensity — which appears to relate to warm-season rainfall depths more than annual rainfall depth - is more closely tied to rainfall runoff and overland flow erosion, then erosion rates of sedimentary deposits and on archaeological sites along the river are not expected to have diminished significantly since the onset of the Early 21st Century Drought. Based on the work of Hereford and others (1993; written commun.) however, recent erosion within the river corridor does not appear to be as severe as that which occurred during the Wet Period, when significant gully erosion was documented from central Marble Canyon to central Grand Canyon. If it is assumed that changes in the frequency of high rainfall intensity events has not significantly diminished, then it is likely that other mechanisms that effect erosion rates are at work, such as the influence of low-intensity, long-duration multiday rainfall events and antecedent moisture (Groisman and others, 2012). Preliminary analysis of 3- to 5-day rainfall accumulations compared with $I_{10}$ as a proxy for antecedent moisture, do not indicate marked differences between the Wet Period and subsequent years with comparable frequencies of high intensity storms $(1999,2003$, and 2012) aside from two 5-day rainfall accumulations of 50 to $60 \mathrm{~mm}$ with an $I_{10}$ near $20 \mathrm{~mm} / \mathrm{hr}$ during the $1979-80 \mathrm{cool}$ season. Additional work to adequately investigate the potential role of antecedent moisture as a factor that influences erosion rates within the region is warranted. If temporal trends in rainfall intensity or multiday volume are not responsible for apparent differences in overland flow and gully erosion, then another possibility outside the scope of our investigation is that changes to the time of concentration (Chin, 2000) for rainfall within local watersheds might have occurred at some locations within the river corridor. Changes in vegetation and topography are two mechanisms by which time of concentration can vary temporally (Chin, 2000; Li and Chibber, 2008). Sankey and others (2015) evaluation of vegetation along the river demonstrates marked increases in vegetation during the Wet Period and more variable changes since that time. Additional analyses of vegetation and topographic changes would be needed to evaluate changes to the time of concentration as an explanation. Identification of significant changes in erosion rates in future studies may also indicate other additional atmospheric or physiographic factors contributing to the erosion of sites and sedimentary deposits along the river that we have not considered.

Our analysis of spatial and temporal variability in rainfall characteristics cannot explain fully the variability in rainfall runoff erosion across the Grand Canyon region, because (1) the monitoring data we analyzed are not spatially continuous, and (2) additional factors, such as differences in geomorphic surfaces and biophysical adjustments and substrates, are necessary to understand differential runoff erosion (Pederson and O'Brien, 2014). Our analyses and the datasets we generated will be useful, however, for scientists to incorporate in a larger framework to test the effects of geomorphic complexity within similar rainfall regimes along the Colorado River, as well as assessing potential mitigation efforts to arrest erosion and gully development in sensitive areas. Continued monitoring of weather parameters, along with quantification of river corridor geomorphic conditions, will be instrumental in refining our understanding of landscape changes in Marble and Grand Canyons.

\section{Conclusions}

In this study, we examined datasets of varying temporal length, resolution, and spatial distribution from monitoring stations in the Grand Canyon region in order to better understand variability in rainfall amount and intensity, and to inform future studies of rainfall runoff as a driver for landscape change in this environment. Short-term, high-resolution data were useful for characterizing the spatial distribution of rainfall among monitoring stations along the river as well as to develop thresholds to define high-intensity, short-duration storms. Results suggest that rainfall among the monitoring stations within the river corridor is spatially correlated at separation distances of tens of kilometers and less, 
and is not correlated at the large elevation differences that separate the Colorado River from the canyon rims. Spatial variability is additionally influenced by canyon and rim physiography, and proximity to important orographic features where rainfall likely concentrates on the rim and subsequently along the river. Relations between daily rainfall depth and intensity developed from shortterm, high-resolution data were applied to lower-resolution, longer-term data to synthesize a long-term record of daily rainfall intensity from 1950-2012; such a dataset did not previously exist. The utility of an estimated daily rainfall intensity record was demonstrated for evaluating the potential for high-intensity, shortduration rainfall as a driver for differences between previously documented overland flow erosion and recent surface changes. The analyses and synthesized intensity records (appendix 4, online only) will be of use in studies that investigate landscape change and the role of geomorphic complexity within similar rainfall regimes in the Grand Canyon region. Additionally, these data can be used for evaluating historic time periods and the role rainfall patterns may have played in significant erosion and gullying within the canyon; particularly for archaeological sites and cultural properties that are currently monitored for damage from erosion. More generally, this study will be useful for efforts to advance understanding of rainfall complexity in deep canyons.

\section{References Cited}

Akaike, H., 1974, A new look at the statistical model identification: Institute of Electrical and Electronics Engineers Transactions on Automatic Control, v. 19, p. 716-723.

Baartman, J.E.M., Jetten, V.G., Ritsema, C.J., and de Vente, J., 2012, Exploring effects of rainfall intensity and duration on soil erosion at the catchment scale using openLISEMPrado catchment, SE Spain: Hydrologic Processes, v. 26, p. 1034-1049.

Basara, J.B., Illston, B.G., Winnings, T.E., Jr., and Fiebrich, C.A., 2009, Evaluation of rainfall measurements from the WXT510 sensor for use in the Oklahoma City Micronet: The Open Atmospheric Science Journal, v. 3, p. 39-47.

Caster, J., Dealy, T., Andrews, T., Fairley, H., Draut, A., and Sankey, J., 2014, Meteorological data for selected sites along the Colorado River Corridor, Arizona, 2011-13: U.S. Geological Survey Open-File Report 2014-1247, 56 p.

Chin, D.A., 2000, Water-resources engineering: Upper Saddle River, NJ, Prentice Hall, 750 p.

Dealy, T.P., Draut, A.E., and Fairley, H.C., 2014, 2010 weather and aeolian sand-transport data from the Colorado River corridor, Grand Canyon, Arizona: U.S. Geological Survey Open-File Report 2014-1135, 90 p.
Draut, A.E., 2012, Effects of river regulation on aeolian landscapes, Colorado River, southwestern USA: Journal of Geophysical Research—Earth Surface, v. 117, F02022, doi:10.1029/2011JF002329.

Draut, A.E., Andrews, T., Fairley, H.C., and Brown, C.R., 2009a, 2007 weather and aeolian sand-transport data from the Colorado River corridor, Grand Canyon, Arizona: U.S. Geological Survey Open-File Report 2009-1095, 110 p.

Draut, A.E., Hazel, J.E., Jr., Fairley, H.C., and Brown, C.R., 2010, Aeolian reworking of sandbars from the March 2008 Glen Canyon Dam high flow experiment in Grand Canyon, in Melis, T.S., Hamill, J.F., Coggins, L.G., Jr., Grams, P.E., Kennedy, T.A., Kubly, D.M., and Ralston, B.E., eds., Proceedings of the Colorado River Basin Science and Resource Management Symposium, November 18-20, 2008, Scottsdale, Ariz.: U.S. Geological Survey Scientific Investigations Report 2010-5135, p. 325-331.

Draut, A.E., and Rubin, D.M., 2005, Measurements of wind, aeolian sand transport, and precipitation in the Colorado River corridor, Grand Canyon, Arizona-November 2003 to December 2004: U.S. Geological Survey Open-File Report 2005-1309, $70 \mathrm{p}$.

Draut, A.E., and Rubin, D.M., 2006, Measurements of wind, aeolian sand transport, and precipitation in the Colorado River corridor, Grand Canyon, Arizona — January 2005 to January 2006: U.S. Geological Survey Open-File Report 2006-1188, $88 \mathrm{p}$.

Draut, A.E., and Rubin, D.M., 2008, The role of eolian sediment in the preservation of archeologic sites along the Colorado River corridor in Grand Canyon National Park, Arizona: U.S. Geological Survey Professional Paper 1756, $71 \mathrm{p}$.

Draut, A.E., Sondossi, H.A., Hazel, J.E., Jr., Andrews, T., Fairley, H.C., Brown, C.R., and Vanaman, K.M., 2009b, 2008 weather and aeolian sand-transport data from the Colorado River corridor, Grand Canyon, Arizona: U.S. Geological Survey Open-File Report 2009-1190, 98 p.

Fairley, H.C., Bungart, P.W., Coder, C.M., Huffman, J., Samples, T.L., and Balsom, J.R., 1994, The Grand Canyon river corridor survey project—Archaeological survey along the Colorado River between Glen Canyon Dam and Separation Canyon: Report prepared for Grand Canyon National Park Service, Cooperative Agreement No. 9AA-40-07920, 276 p.

Farmer, E.E., and Fletcher, J.E., 1972, Some intra-storm characteristics of high intensity rainfall bursts: Proceedings of Geilo, Norway Symposium, July 31-August 5, p. 525-531.

Griffiths, R.E., Topping, D.J., Anderson, R.S., Hancock, G.S., and Melis, T.S., 2014, Design of a sediment-monitoring gaging network on ephemeral tributaries of the Colorado River in Glen, Marble, and Grand Canyons, Arizona: U.S. Geological Survey Open-File Report 2014-1137, 21 p. 
Groisman, P.Y., Knight, R.W., Easterling, D.R., Karl, T.R., Hegerl, G., and Razuvaev, V.A.N., 2005, Trends in intense precipitation in the climate record: Journal of Climate, v. 18, no. 9, p. 1326-1350.

Groisman, P.Y., Knight, R.W., and Karl, T.R., 2001, Heavy precipitation and high streamflow in the contiguous United States-Trends in the twentieth century: Bulletin of the American Meteorological Society, v. 82, no. 2, p. 219-246.

Groisman, P.Y., Knight, R.W., and Karl, T.R., 2012, Changes in intense precipitation over the central United States: Bulletin of the American Meteorological Society, v. 13, p. 47-66.

Hadley, R.F., and Lusby, G.C., 1967, Runoff and hillslope erosion resulting from a high-intensity thunderstorm near Mack, western Colorado: Water Resources Research, v. 3, no. 1, p. 139-143, doi:10.1029/WR003i001p00139.

Hereford, R., Bennett, G.E., and Fairley, H.C., 2014, Precipitation variability of the Grand Canyon region, 1893 through 2009, and its implications for studying effects of gullying of Holocene terraces and associated archeological sites in Grand Canyon, Arizona: U.S. Geological Survey Open-File Report 2014-1006, 23 p.

Hereford, R., Fairley, H.C., Thompson, K.S., and Balsom, J.R., 1993, Surficial geology, geomorphology, and erosion of archeologic sites along the Colorado River, eastern Grand Canyon, Grand Canyon National Park, Arizona: U.S. Geological Survey Open-File Report 93-517, 46 p.

Hereford, R., and Webb, R.H., 1992, Historic variation of warmseason rainfall, Southern Colorado Plateau, Southwestern U.S.A: Climate Change, v. 22, p. 239-256.

Jones, A.T., 1986, A cross-section of Grand Canyon archaeologyExcavations at five sites along the Colorado River: Western Archaeological and Conservation Center Publications in Anthropology No. 28, USDI National Park Service, Western Archaeological and Conservation Center, Tucson, Ariz., 367 p.

Karl, T.R., and Knight, R.W., 1998, Secular trends of precipitation amount, frequency, and intensity in the United States: Bulletin of the American Meteorological Society, v. 79, p. 1107-1119.

Kunkel, K.E., Easterling, D.R., Kristovich, D.A., Gleason, B., Stoecker, L., and Smith, R., 2012, Meteorological causes of secular variations in observed extreme precipitation events for the conterminous United States: Journal of Hydrometeorology, v. 13, p. 1131-1141.

Li, M.-H., and Chibber, P., 2008, Overland flow time of concentration on very flat terrains: Transportation Research Record-Journal of the Transportation Research Board, v. 2060, p. 133-140.
Mondal, A., and Mujumdar, P.P., 2015, Modeling non-stationarity in intensity, duration and frequency of extreme rainfall over India: Journal of Hydrology, v. 521, p. 217-231.

National Oceanic and Atmospheric Administration, 2014, National Weather Service Instruction 10-1302-Requirements and Standards for NWS Climate Observations: National Oceanic and Atmospheric Administration Report NWSI 10-1302, 23 p.

Pederson, J.L., and O'Brien, G.R., 2014, Patterns in the landscape and erosion of cultural sites along the Colorado River corridor in Grand Canyon, USA: Geoarchaeology, v. 29, p. 431-447.

Pederson, J.L., Petersen, P.A., and Dierker, J.L., 2006, Gullying and erosion control at archaeological sites in Grand Canyon, Arizona: Earth Surface Processes and Landforms, v. 31, p. 507-525.

Renard, K.G., Foster, G.R., and Weesies, G.A., 1997, Predicting soil erosion by water; a guide to conservation planning with the revised universal soil loss equation (RUSLE): Agriculture Handbook n. 703, U.S. Department of Agriculture Agricultural Research Service, 404 p.

Robichaud, P.R., Wagenbrenner, J.W., Brown, R.E., and Spigel, K.M., 2009, Three years of hillslope sediment yields following the Valley Complex fires, western Montana: U.S. Department of Agriculture, Forest Service, Rocky Mountain Research Station, Fort Collins, Colo., Research Paper RMRS-RP-77, 8 p.

Sankey, J.B., Ralston, B.E., Grams, P.E., Schmidt, J.C., and Cagney, L.E., 2015, Riparian vegetation, Colorado River, and climate-Five decades of spatio-temporal dynamics in the Grand Canyon with river regulations: Journal of Geophysical Research, Biogeosciences, v. 120, doi: 10.1002/2015JG002991.

Schott, N.D., Hazel, J.E., Jr., Fairley, H.C., Kaplinski, M., and Parnell, R.A., 2014, Gully monitoring at two locations in the Grand Canyon National Park, Arizona, 1996-2010, with emphasis on documenting effects of the March 2008 high-flow experiment: U.S. Geological Survey Open-File Report 2014 $1211,32 \mathrm{p}$.

Topping, D.J., Rubin D.M., Nelson, J.M., Kinzel, P.J., III, and Corson, I.C., 2000, Colorado River sediment transport 2. Systematic bed-elevation and grain-size effects of sand supply limitation: Water Resources Research, v. 36, p. 543-570.

Webb, R.H., Griffiths, P.G., Melis, T.S., and Hartley, D.R., 2000, Sediment delivery by ungaged tributaries of the Colorado River in Grand Canyon, Arizona: U.S. Geological Survey Water Resources Investigation Report 00-4055, 67 p. 


\section{Appendixes}




\section{Appendix 1. National Ocean and Atmospheric Administration Cooperative Observer Stations within the Grand Canyon Region}

Table 1-1. Cooperative Observer (COOP) station summary.

[Station information summaries were adapted from the National Climate Data Center: http://www.ncdc.noaa.gov/cdo-web/. * indicates stations not used in the regional daily average presented in figure 7 and table 1 in the main report]

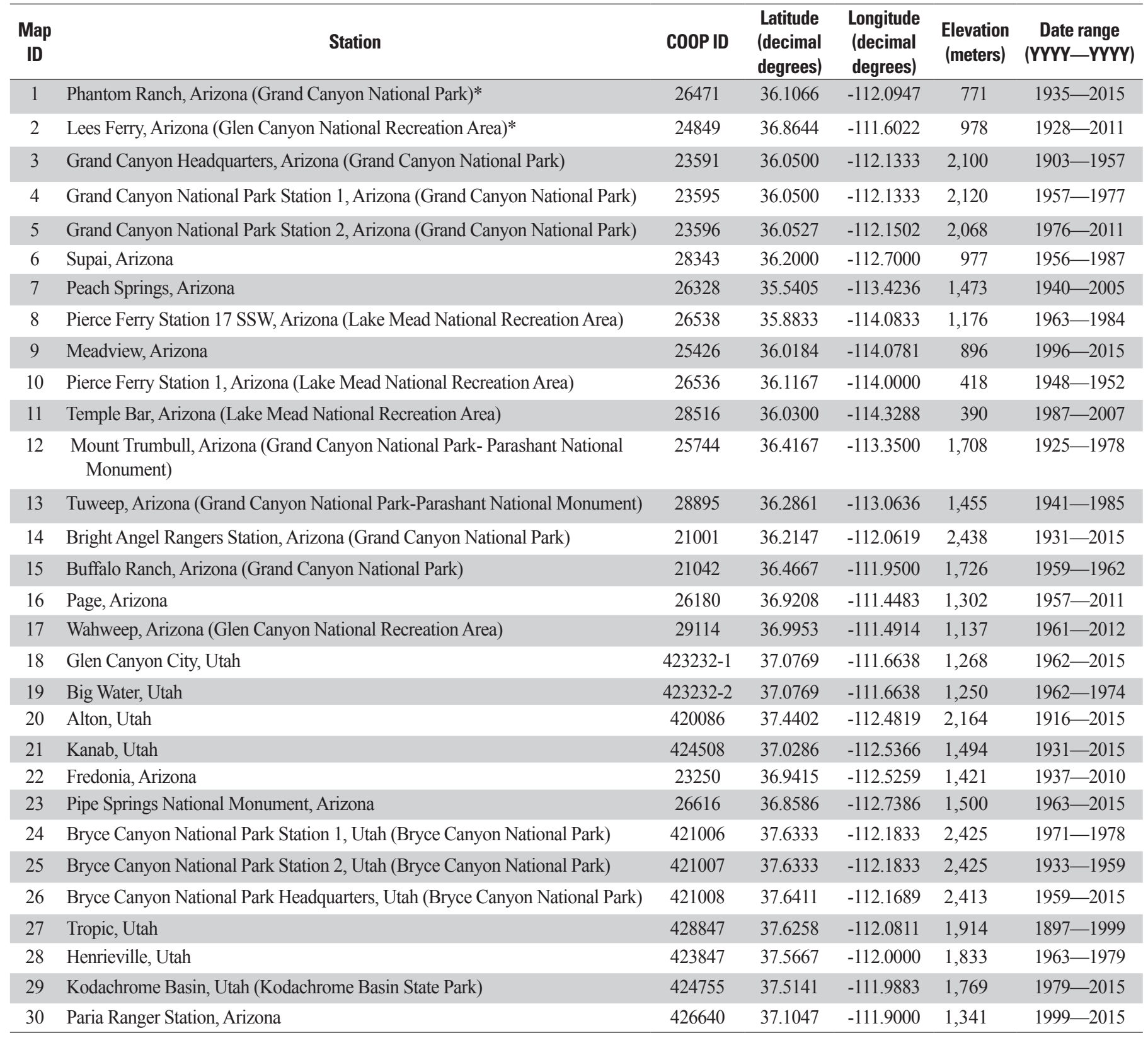




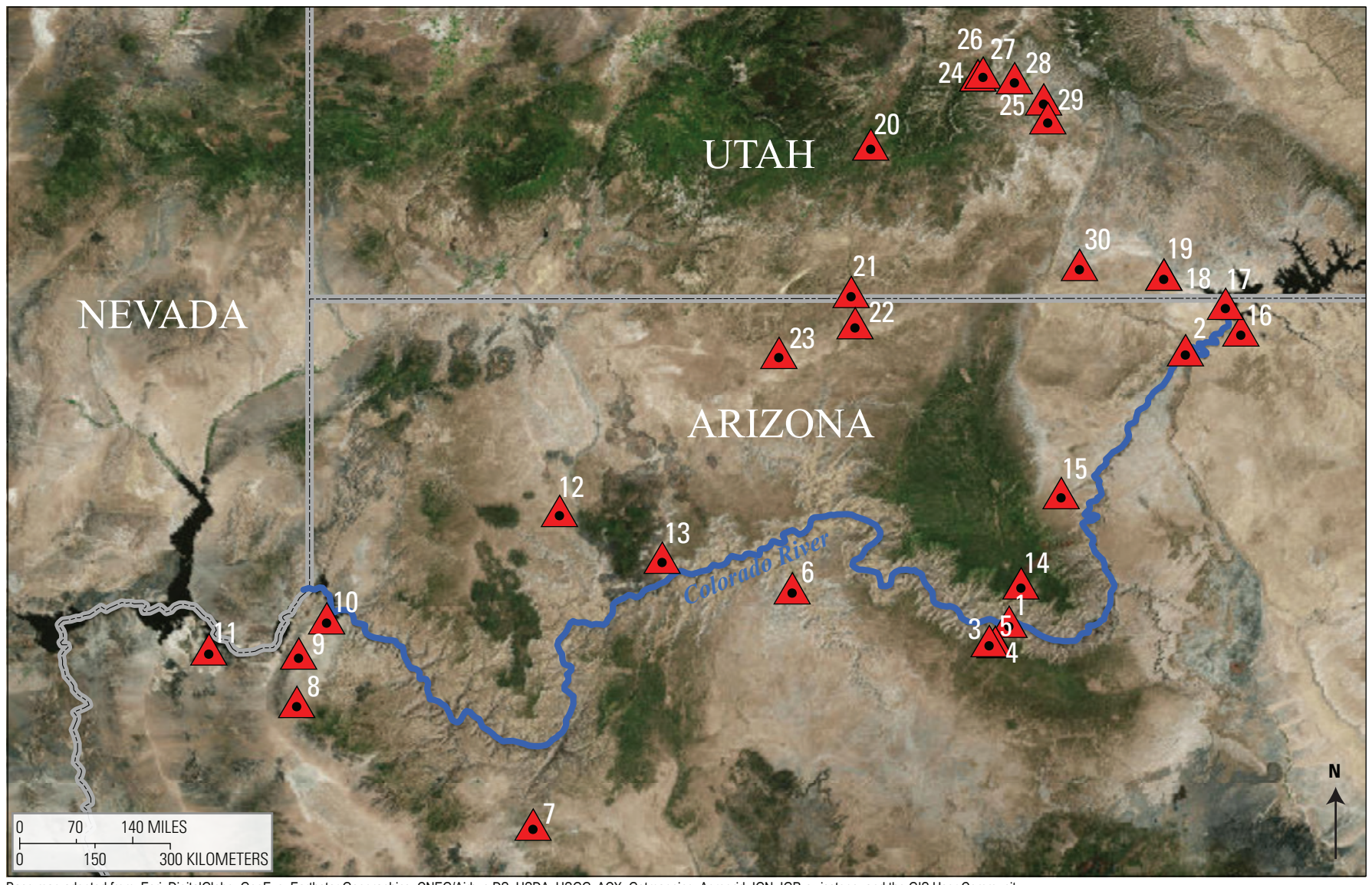

Base map adopted from: Esri, DigitalGlobe, GeoEye, Earthstar Geographics, CNEG/Airbus DS, USDA, USGG, ACX, Getmapping, Aerogrid, IGN, IGP, swisstopo, and the GIS User Community

Figure 1-1. National Ocean and Atmospheric Administration Cooperative Observer station locations (red triangles) used within the Grand Canyon region. Grand Canyon region designation adapted from Hereford and others (2014). Station labels correspond to the Map ID in table 1-1. Study reach of the Colorado River in blue. 


\section{Appendix 2. Akaike Information Criteria Calculation Results for Multi-Station Geographic Groups}

The Akaike Information Criteria (AIC) statistical analysis was used to compare linear regression models from individual stations to regression equations calculated from combined data in multi-station geographic groups (table 1 in the main report). Tables 2-1-2-5 provide the results of those calculations, including important intermediary statistics such as the sum of squared errors (SSE) and number of paired observations $(n)$ used in the calculation. Station locations are shown in figure 2-1.

Table 2-1. Results of Akaike Information Criteria (AIC) on select stations using regression equations derived separately from each station. SSE, sum of squared errors; $n$, number of paired observations.

\begin{tabular}{|c|c|c|c|c|c|c|c|c|c|c|}
\hline \multirow{2}{*}{ Geographic group } & \multirow{2}{*}{ Station } & \multicolumn{3}{|c|}{ Dry season } & \multicolumn{3}{|c|}{ Warm season } & \multicolumn{3}{|c|}{ Cool season } \\
\hline & & SSE & $n$ & AIC & SSE & $n$ & AIC & SSE & $n$ & AIC \\
\hline \multirow[t]{5}{*}{ CICSraw } & AZ G:03:0072 & 11.196 & 52 & -75.858 & 21.906 & 132 & -233.078 & 25.554 & 127 & -199.630 \\
\hline & AZ B:11:0281 & 18.553 & 71 & -91.287 & 20.945 & 102 & -157.473 & 37.508 & 142 & -185.041 \\
\hline & AZ C:13:0346 & 14.872 & 71 & -106.989 & 17.067 & 107 & -192.418 & 24.063 & 122 & -194.047 \\
\hline & AZ C:13:0006 & 13.966 & 77 & -127.453 & 16.818 & 75 & -108.129 & 28.171 & 134 & -204.979 \\
\hline & AZ C:05:0031 & 13.898 & 90 & -164.127 & 20.057 & 103 & -164.522 & 27.929 & 114 & -156.343 \\
\hline \multirow[t]{5}{*}{ CICScorr } & AZ G:03:0072 & 11.196 & 52 & -75.858 & 21.906 & 132 & -233.078 & 25.554 & 127 & -199.630 \\
\hline & AZ B:11:0281 & 18.553 & 71 & -91.287 & 20.945 & 102 & -157.473 & 37.508 & 142 & -185.041 \\
\hline & AZ C:13:0346 & 14.872 & 71 & -106.989 & 17.067 & 107 & -192.418 & 24.063 & 122 & -194.047 \\
\hline & AZ C:13:0006 & 13.966 & 77 & -127.453 & 16.818 & 75 & -108.129 & 28.171 & 134 & -204.979 \\
\hline & AZ C:05:0031 & 13.898 & 90 & -164.127 & 20.057 & 103 & -164.522 & 27.929 & 114 & -156.343 \\
\hline \multirow{5}{*}{$\begin{array}{l}\text { MCGN- Kaibab } \\
\text { Plateau }\end{array}$} & North-1 & 7.900 & 55 & -102.727 & 25.084 & 113 & -166.083 & 29.324 & 167 & -286.513 \\
\hline & Tater-1 & 13.461 & 84 & -149.809 & 35.727 & 139 & -184.842 & 27.739 & 198 & -385.157 \\
\hline & Tater-2 & 13.327 & 95 & -182.588 & 37.748 & 122 & -139.116 & 32.722 & 198 & -352.445 \\
\hline & Kane-2 & 16.385 & 82 & -128.049 & 35.371 & 121 & -144.818 & 28.081 & 198 & -382.729 \\
\hline & Kane-1 & 9.804 & 82 & -170.159 & 29.068 & 109 & -140.067 & 33.812 & 198 & -345.958 \\
\hline \multirow[t]{5}{*}{ MCGN - South Rim } & Water-2 & 12.037 & 56 & -82.092 & 17.001 & 81 & -122.457 & 20.962 & 129 & -230.407 \\
\hline & Cedar-1 & 10.009 & 40 & -51.414 & 30.176 & 87 & -88.122 & 17.923 & 115 & -209.770 \\
\hline & Tan-1 & 8.395 & 31 & -36.495 & 27.905 & 101 & -125.918 & 26.655 & 143 & -236.223 \\
\hline & Lime & 7.534 & 46 & -79.223 & 16.679 & 88 & -142.362 & 22.318 & 118 & -192.506 \\
\hline & Water-G & 6.844 & 56 & -113.712 & 12.040 & 77 & -138.880 & 18.343 & 112 & -198.637 \\
\hline \multirow[t]{6}{*}{ MCGN North Rim } & North-G & 6.274 & 42 & -75.855 & 22.152 & 88 & -117.386 & 13.680 & 122 & -262.949 \\
\hline & Badger-1 & 6.318 & 54 & -111.860 & 22.960 & 86 & -109.570 & 23.849 & 172 & -335.830 \\
\hline & Badger-G & 10.573 & 53 & -81.438 & 26.992 & 77 & -76.715 & 21.927 & 116 & -189.243 \\
\hline & House-1 & 7.306 & 54 & -104.015 & 25.631 & 99 & -129.781 & 29.475 & 162 & -272.059 \\
\hline & House-2 & 6.714 & 64 & -140.302 & 25.361 & 91 & -112.265 & 19.727 & 128 & -235.365 \\
\hline & Rider-G & 5.621 & 31 & -48.934 & 18.502 & 86 & -128.136 & 16.487 & 101 & -179.065 \\
\hline
\end{tabular}


Table 2-2. Results of Akaike Information Criteria (AIC) on select stations using regression equations derived from the combined U.S. Geological Survey Grand Canyon Monitoring and Research Center's river corridor stations ( GICS $_{\text {raw }}$ ).

[GICSraw represents GICS data without a correction factor applied to make them comparable with tipping-bucket rain gauges. SSE, sum of squared errors; $n$, number of paired observations]

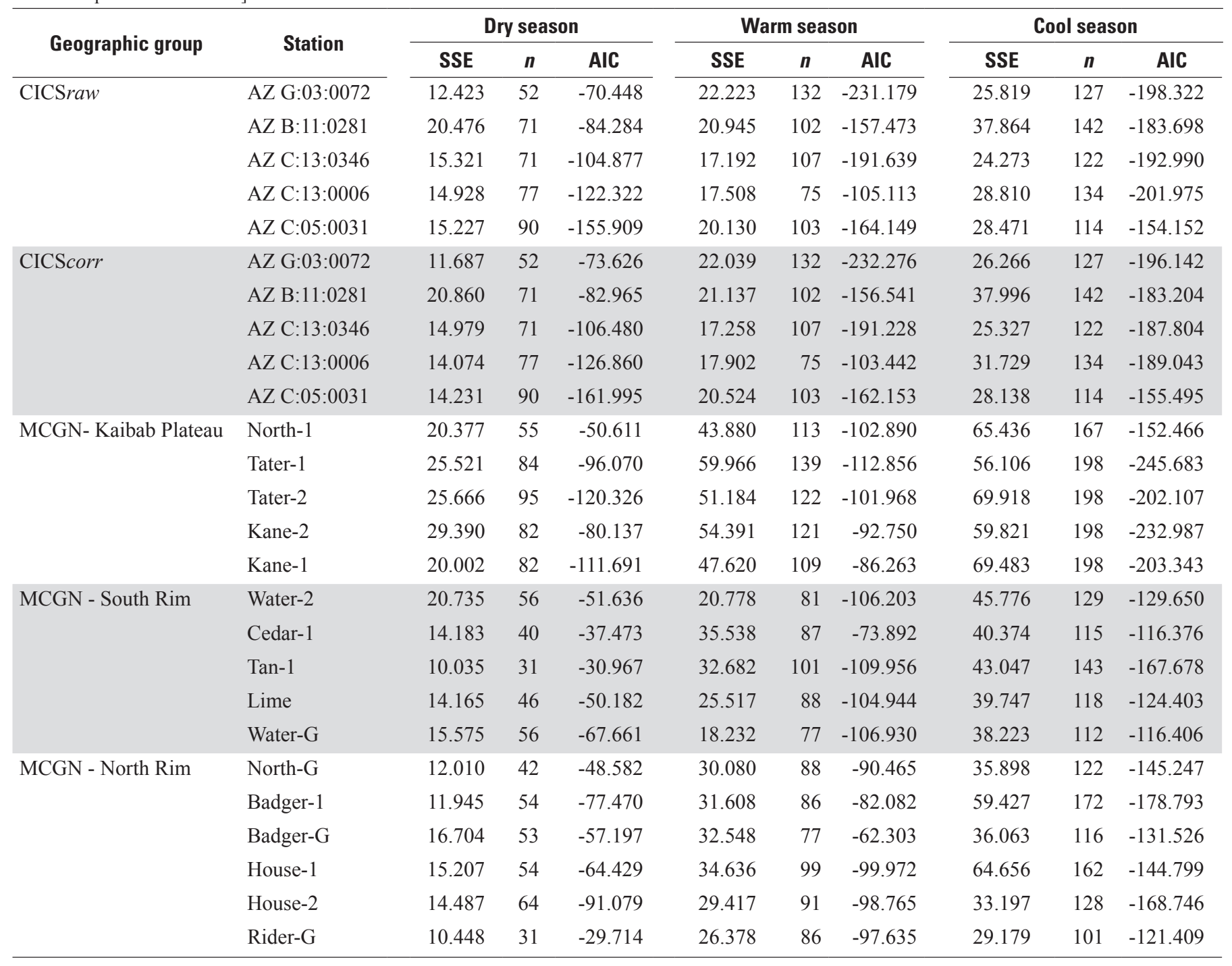


Table 2-3. Results of Akaike Information Criteria (AIC) on select stations using regression equations derived from the combined U.S. Geological Survey Grand Canyon Monitoring and Research Center's river corridor stations that had a correction factor applied to make them comparable with tipping-bucket rain gauges $\left(\mathrm{GICS}_{\text {corr }}\right)$. SSE, sum of squared errors; $n$, number of paired observations.

\begin{tabular}{|c|c|c|c|c|c|c|c|c|c|c|}
\hline \multirow{2}{*}{ Geographic group } & \multirow{2}{*}{ Station } & \multicolumn{3}{|c|}{ Dry season } & \multicolumn{3}{|c|}{ Warm season } & \multicolumn{3}{|c|}{ Cool season } \\
\hline & & SSE & $n$ & AIC & SSE & $n$ & AIC & SSE & $n$ & AIC \\
\hline \multirow[t]{5}{*}{ CICSraw } & AZ G:03:0072 & 13.807 & 52 & -64.954 & 22.904 & 132 & -227.195 & 27.679 & 127 & -189.488 \\
\hline & AZ B:11:0281 & 20.975 & 71 & -82.574 & 21.136 & 102 & -156.546 & 40.312 & 142 & -174.804 \\
\hline & AZ C:13:0346 & 16.547 & 71 & -99.411 & 17.528 & 107 & -189.566 & 25.435 & 122 & -187.285 \\
\hline & AZ C:13:0006 & 16.742 & 77 & -113.494 & 17.394 & 75 & -105.600 & 28.325 & 134 & -204.248 \\
\hline & AZ C:05:0031 & 17.343 & 90 & -144.195 & 20.123 & 103 & -164.186 & 30.876 & 114 & -144.910 \\
\hline \multirow[t]{5}{*}{ CICScorr } & AZ G:03:0072 & 12.424 & 52 & -70.444 & 22.224 & 132 & -231.173 & 25.819 & 127 & -198.322 \\
\hline & AZ B:11:0281 & 20.476 & 71 & -84.284 & 20.945 & 102 & -157.473 & 37.864 & 142 & -183.698 \\
\hline & AZ C:13:0346 & 15.321 & 71 & -104.873 & 17.192 & 107 & -191.637 & 24.273 & 122 & -192.990 \\
\hline & AZ C:13:0006 & 14.930 & 77 & -122.316 & 17.507 & 75 & -105.116 & 28.810 & 134 & -201.974 \\
\hline & AZ C:05:0031 & 15.228 & 90 & -155.901 & 20.130 & 103 & -164.151 & 28.471 & 114 & -154.152 \\
\hline \multirow[t]{5}{*}{ MCGN- Kaibab Plateau } & North-1 & 19.029 & 55 & -54.375 & 41.826 & 113 & -108.307 & 63.809 & 167 & -156.670 \\
\hline & Tater-1 & 25.346 & 84 & -96.650 & 57.456 & 139 & -118.800 & 49.703 & 198 & -269.677 \\
\hline & Tater-2 & 26.198 & 95 & -118.379 & 49.559 & 122 & -105.905 & 63.369 & 198 & -221.579 \\
\hline & Kane-2 & 29.830 & 82 & -78.918 & 52.243 & 121 & -97.625 & 56.486 & 198 & -244.346 \\
\hline & Kane-1 & 20.399 & 82 & -110.083 & 45.797 & 109 & -90.517 & 57.676 & 198 & -240.217 \\
\hline \multirow[t]{5}{*}{ MCGN - South Rim } & Water-2 & 23.171 & 56 & -45.416 & 20.699 & 81 & -106.513 & 49.406 & 129 & -119.806 \\
\hline & Cedar-1 & 14.000 & 40 & -37.993 & 34.163 & 87 & -77.324 & 39.706 & 115 & -118.294 \\
\hline & Tan-1 & 10.402 & 31 & -29.852 & 32.014 & 101 & -112.043 & 48.383 & 143 & -150.969 \\
\hline & Lime & 15.115 & 46 & -47.194 & 25.228 & 88 & -105.947 & 42.345 & 118 & -116.930 \\
\hline & Water-G & 19.078 & 56 & -56.301 & 18.588 & 77 & -105.441 & 42.977 & 112 & -103.277 \\
\hline \multirow[t]{6}{*}{ MCGN - North Rim } & North-G & 13.517 & 42 & -43.617 & 29.896 & 88 & -91.006 & 37.381 & 122 & -140.309 \\
\hline & Badger-1 & 12.966 & 54 & -73.038 & 31.077 & 86 & -83.537 & 58.029 & 172 & -182.886 \\
\hline & Badger-G & 19.069 & 53 & -50.178 & 33.155 & 77 & -60.881 & 39.028 & 116 & -122.361 \\
\hline & House-1 & 15.203 & 54 & -64.445 & 33.396 & 99 & -103.582 & 64.356 & 162 & -145.553 \\
\hline & House-2 & 17.606 & 64 & -78.601 & 29.224 & 91 & -99.364 & 34.793 & 128 & -162.735 \\
\hline & Rider-G & 11.663 & 31 & -26.304 & 26.520 & 86 & -97.176 & 30.050 & 101 & -118.439 \\
\hline
\end{tabular}


Table 2-4. Results of Akaike Information Criteria (AIC) on select stations using regression equations derived from the combined U.S. Geological Survey Marble Canyon Gauge Network lower elevation tipping bucket rain gauges (MCGN). SSE, sum of squared errors; $n$, number of paired observations.

\begin{tabular}{|c|c|c|c|c|c|c|c|c|c|c|}
\hline \multirow{2}{*}{ Geographic group } & \multirow{2}{*}{ Station } & \multicolumn{3}{|c|}{ Dry season } & \multicolumn{3}{|c|}{ Warm season } & \multicolumn{3}{|c|}{ Cool season } \\
\hline & & SSE & $n$ & AIC & SSE & $n$ & AIC & SSE & $n$ & AIC \\
\hline \multirow[t]{5}{*}{ CICSraw } & AZ G:03:0072 & 34.684 & 52 & -17.059 & 48.383 & 132 & -128.483 & 96.805 & 127 & -30.479 \\
\hline & AZ B:11:0281 & 67.956 & 71 & 0.889 & 38.561 & 102 & -95.218 & 93.384 & 142 & -55.514 \\
\hline & AZ C:13:0346 & 46.098 & 71 & -26.665 & 39.464 & 107 & -102.727 & 89.106 & 122 & -34.332 \\
\hline & AZ C:13:0006 & 45.139 & 77 & -37.122 & 26.833 & 75 & -73.090 & 87.156 & 134 & -53.639 \\
\hline & AZ C:05:0031 & 62.429 & 90 & -28.920 & 38.575 & 103 & -97.159 & 82.288 & 114 & -33.161 \\
\hline \multirow[t]{5}{*}{ CICScorr } & AZ G:03:0072 & 41.166 & 52 & -8.148 & 52.958 & 132 & -116.556 & 109.811 & 127 & -14.470 \\
\hline & AZ B:11:0281 & 80.270 & 71 & 12.713 & 41.217 & 102 & -88.423 & 101.060 & 142 & -44.296 \\
\hline & AZ C:13:0346 & 55.424 & 71 & -13.584 & 41.973 & 107 & -96.131 & 109.204 & 122 & -9.518 \\
\hline & AZ C:13:0006 & 55.413 & 77 & -21.332 & 30.086 & 75 & -64.506 & 107.391 & 134 & -25.663 \\
\hline & AZ C:05:0031 & 78.861 & 90 & -7.891 & 42.552 & 103 & -87.052 & 97.794 & 114 & -13.480 \\
\hline \multirow[t]{5}{*}{ MCGN- Kaibab Plateau } & North-1 & 10.302 & 55 & -88.125 & 26.966 & 113 & -157.907 & 30.950 & 167 & -277.501 \\
\hline & Tater-1 & 14.080 & 84 & -146.032 & 39.464 & 139 & -171.013 & 34.577 & 198 & -341.523 \\
\hline & Tater-2 & 14.910 & 95 & -171.926 & 38.764 & 122 & -135.878 & 36.798 & 198 & -329.200 \\
\hline & Kane-2 & 17.309 & 82 & -123.551 & 37.895 & 121 & -136.477 & 31.102 & 198 & -362.497 \\
\hline & Kane-1 & 10.987 & 82 & -160.817 & 31.933 & 109 & -129.820 & 40.258 & 198 & -311.407 \\
\hline \multirow[t]{5}{*}{ MCGN - South Rim } & Water-2 & 12.238 & 56 & -81.166 & 17.262 & 81 & -121.220 & 21.615 & 129 & -226.450 \\
\hline & Cedar-1 & 10.427 & 40 & -49.779 & 31.545 & 87 & -84.260 & 20.942 & 115 & -191.866 \\
\hline & Tan-1 & 8.617 & 31 & -35.686 & 28.265 & 101 & -124.622 & 30.713 & 143 & -215.957 \\
\hline & Lime & 7.690 & 46 & -78.283 & 16.947 & 88 & -140.957 & 22.668 & 118 & -190.667 \\
\hline & Water-G & 8.083 & 56 & -104.394 & 12.157 & 77 & -138.137 & 19.538 & 112 & -191.568 \\
\hline \multirow[t]{6}{*}{ MCGN - North Rim } & North-G & 6.282 & 42 & -75.798 & 22.440 & 88 & -116.253 & 13.961 & 122 & -260.462 \\
\hline & Badger-1 & 6.340 & 54 & -111.670 & 23.061 & 86 & -109.192 & 26.577 & 172 & -317.201 \\
\hline & Badger-G & 11.219 & 53 & -78.290 & 29.715 & 77 & -69.317 & 22.994 & 116 & -183.730 \\
\hline & House-1 & 8.084 & 54 & -98.549 & 25.704 & 99 & -129.499 & 31.050 & 162 & -263.622 \\
\hline & House-2 & 9.094 & 64 & -120.884 & 25.688 & 91 & -111.100 & 20.295 & 128 & -231.733 \\
\hline & Rider-G & 5.895 & 31 & -47.455 & 18.983 & 86 & -125.930 & 16.801 & 101 & -177.164 \\
\hline
\end{tabular}


Table 2-5. Results of Akaike Information Criteria (AIC) on select stations using regression equations derived from the combined U.S. Geological Survey Marble Canyon Gauge Network higher elevation tipping bucket rain gauges located on the Kaibab Plateau (MCGNKaibab). SSE, sum of squared errors; $n$, number of paired observations.

\begin{tabular}{|c|c|c|c|c|c|c|c|c|c|c|}
\hline \multirow{2}{*}{ Geographic group } & \multirow{2}{*}{ Station } & \multicolumn{3}{|c|}{ Dry season } & \multicolumn{3}{|c|}{ Warm season } & \multicolumn{3}{|c|}{ Cool season } \\
\hline & & SSE & $n$ & AIC & SSE & $n$ & AIC & SSE & $n$ & AIC \\
\hline \multirow[t]{5}{*}{ CICSraw } & AZ G:03:0072 & 41.327 & 52 & -7.946 & 59.787 & 132 & -100.546 & 102.629 & 127 & -23.060 \\
\hline & AZ B:11:0281 & 78.768 & 71 & 11.372 & 47.531 & 102 & -73.887 & 102.481 & 142 & -42.313 \\
\hline & AZ C:13:0346 & 54.849 & 71 & -14.325 & 50.511 & 107 & -76.319 & 88.332 & 122 & -35.396 \\
\hline & AZ C:13:0006 & 54.068 & 77 & -23.225 & 31.428 & 75 & -61.234 & 86.410 & 134 & -54.791 \\
\hline & AZ C:05:0031 & 74.641 & 90 & -12.841 & 46.045 & 103 & -78.925 & 83.431 & 114 & -31.588 \\
\hline \multirow[t]{5}{*}{ CICScorr } & AZ G:03:0072 & 48.311 & 52 & 0.173 & 63.582 & 132 & -92.421 & 94.792 & 127 & -33.148 \\
\hline & AZ B:11:0281 & 92.306 & 71 & 22.632 & 48.982 & 102 & -70.818 & 103.390 & 142 & -41.059 \\
\hline & AZ C:13:0346 & 64.712 & 71 & -2.584 & 51.727 & 107 & -73.774 & 103.940 & 122 & -15.546 \\
\hline & AZ C:13:0006 & 65.205 & 77 & -8.803 & 34.190 & 75 & -54.917 & 101.257 & 134 & -33.543 \\
\hline & AZ C:05:0031 & 93.597 & 90 & 7.527 & 136.156 & 103 & 32.745 & 94.580 & 114 & -17.290 \\
\hline \multirow[t]{5}{*}{ MCGN- Kaibab Plateau } & North-1 & 8.173 & 55 & -100.858 & 25.112 & 113 & -165.956 & 29.918 & 167 & -283.160 \\
\hline & Tater-1 & 13.642 & 84 & -148.683 & 35.850 & 139 & -184.365 & 28.245 & 198 & -381.572 \\
\hline & Tater-2 & 13.366 & 95 & -182.313 & 38.128 & 122 & -137.895 & 32.941 & 198 & -351.123 \\
\hline & Kane-2 & 16.514 & 82 & -127.406 & 35.382 & 121 & -144.781 & 28.424 & 198 & -380.321 \\
\hline & Kane-1 & 9.834 & 82 & -169.910 & 29.208 & 109 & -139.543 & 34.831 & 198 & -340.076 \\
\hline \multirow[t]{5}{*}{ MCGN - South Rim } & Water-2 & 13.551 & 56 & -75.456 & 19.860 & 81 & -109.865 & 25.588 & 129 & -204.680 \\
\hline & Cedar-1 & 10.261 & 40 & -50.422 & 33.425 & 87 & -79.224 & 18.285 & 115 & -207.469 \\
\hline & Tan-1 & 9.723 & 31 & -31.943 & 30.793 & 101 & -115.971 & 39.136 & 143 & -181.299 \\
\hline & Lime & 7.799 & 46 & -77.632 & 18.356 & 88 & -133.931 & 26.633 & 118 & -171.645 \\
\hline & Water-G & 9.911 & 56 & -92.976 & 13.608 & 77 & -129.451 & 24.585 & 112 & -165.835 \\
\hline \multirow[t]{6}{*}{ MCGN - North Rim } & North-G & 6.871 & 42 & -72.036 & 24.291 & 88 & -109.275 & 37.381 & 122 & -140.309 \\
\hline & Badger-1 & 7.436 & 54 & -103.061 & 24.866 & 86 & -102.714 & 24.672 & 172 & -329.992 \\
\hline & Badger-G & 13.042 & 53 & -70.310 & 34.796 & 77 & -57.162 & 28.235 & 116 & -159.912 \\
\hline & House-1 & 7.343 & 54 & -103.745 & 27.106 & 99 & -124.241 & 30.185 & 162 & -268.203 \\
\hline & House-2 & 12.830 & 64 & -98.855 & 28.622 & 91 & -101.258 & 24.085 & 128 & -209.818 \\
\hline & Rider-G & 6.756 & 31 & -43.229 & 20.872 & 86 & -117.772 & 20.410 & 101 & -157.507 \\
\hline
\end{tabular}




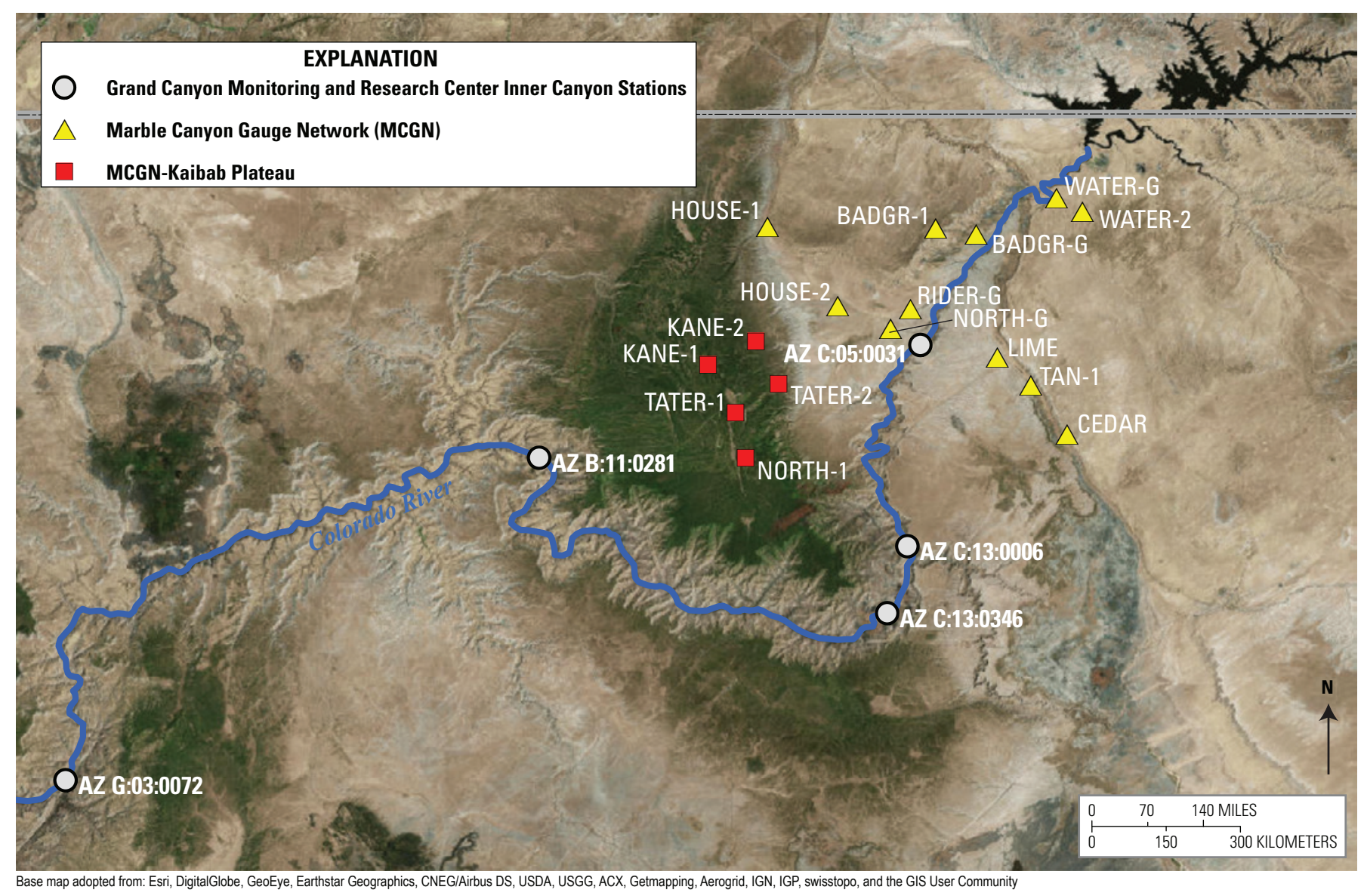

Figure 2-1. Map of station locations used in the Akaike Information Criteria (AIC) analysis. Station labels refer to the station designations used in tables 2-1-2-5. Study reach of the Colorado River in blue. 


\section{Appendix 3. Plot of rainfall depth-intensity relation for multi- station geographic groups.}

\section{U.S. Geological Survey Grand Canyon Monitoring and Research Center inner canyon stations (GICS).}

The following plots (figs. 3-1 and 3-2) represent maximum daily 10-minute rainfall intensity as a function of daily rainfall depth (daily accumulation) for observed rainfall during the 2007-10 assessment period (GICSraw) and for rainfall records corrected with Basara and others (2009) coefficient of compatibility with tipping bucket rain gauges (GICScorr). Plots are presented by season (dry season from April 1 to June 30, warm season from July 1 to October 7, and cool season from October 8 through March 31) in log space to reduce skewness and heteroscedasticity.

\section{Marble Canyon Gauge Network stations (MCGN).}

The following plots (figs. 3-3 and 3-4) represent maximum daily 10-minute rainfall intensity as a function of daily rainfall depth (daily accumulation) for observed rainfall during the 2007-10 assessment period for stations within the Marble Canyon Gauge Network on the Kaibab Plateau (MCGN -Kaibab) and lower elevation stations. Plots are presented by season (dry season from April 1 to June 30, warm season from July 1 to October 7, and cool season from October 8 through March 31) in log space to reduce skewness and heteroscedasticity.
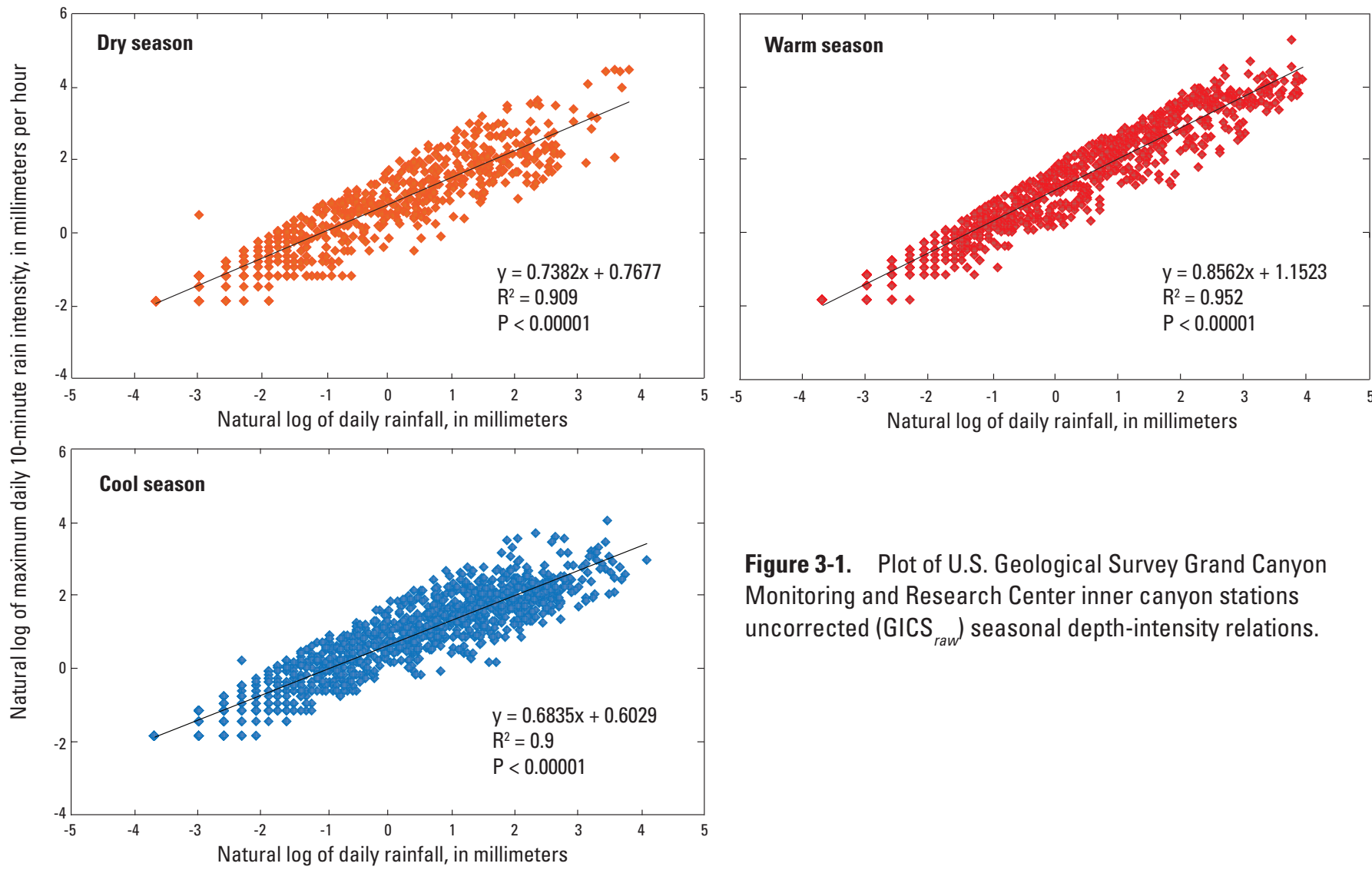

Figure 3-1. Plot of U.S. Geological Survey Grand Canyon Monitoring and Research Center inner canyon stations uncorrected $\left(\right.$ GICS $_{\text {raw }}$ ) seasonal depth-intensity relations. 

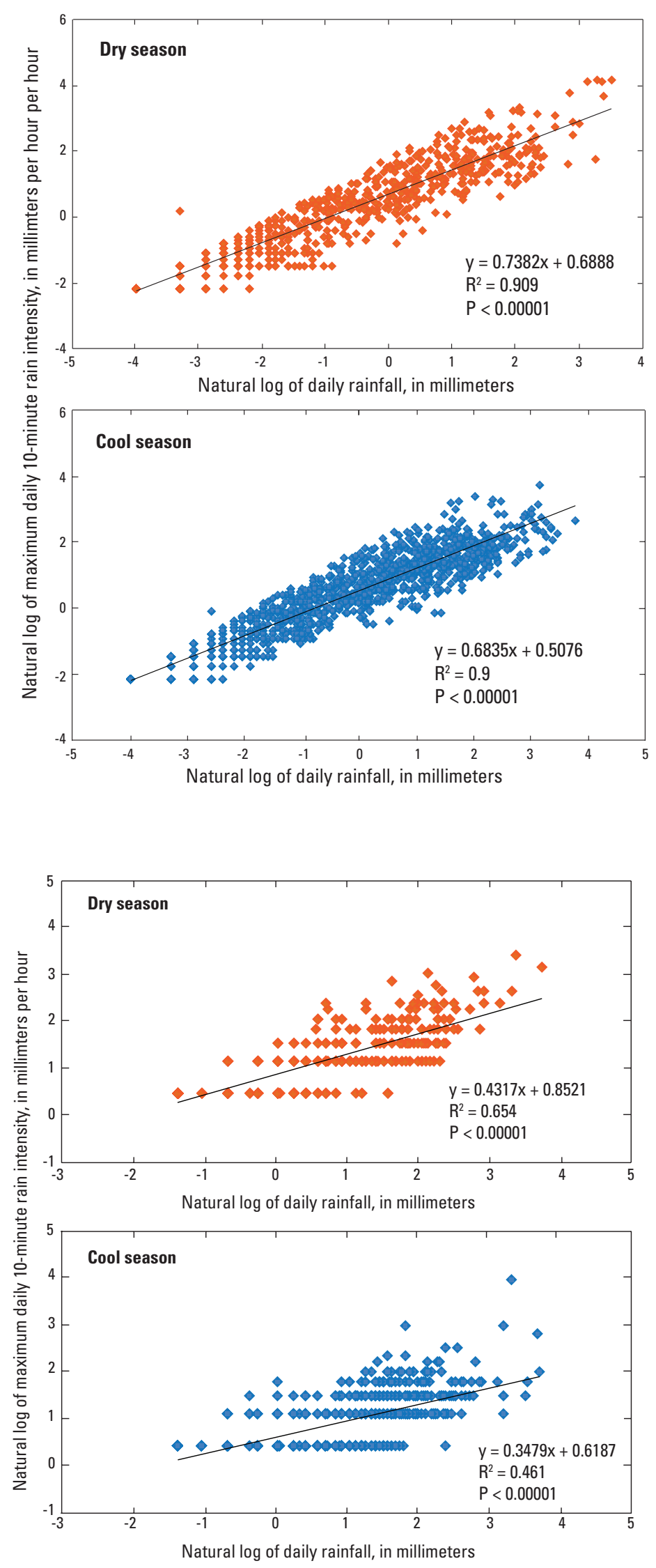

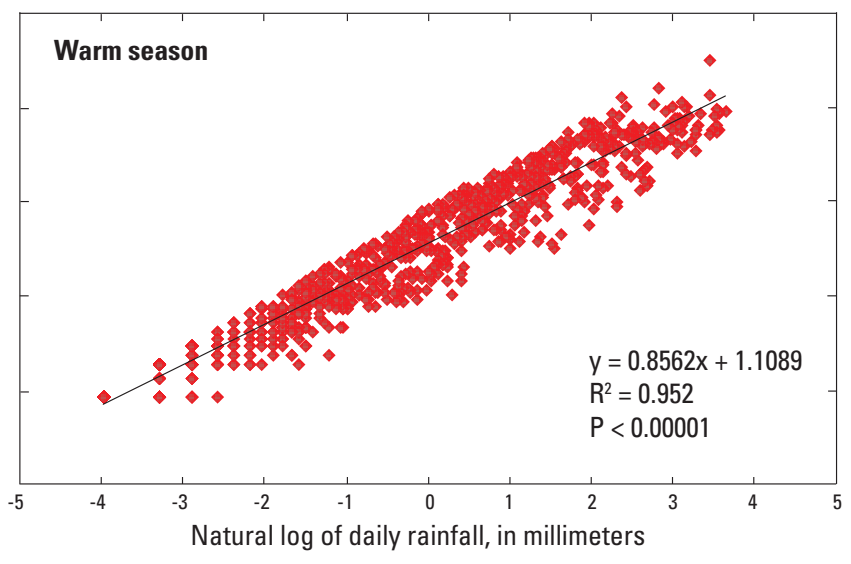

Figure 3-2. Plot of Plot of U.S. Geological Survey Grand Canyon Monitoring and Research Center inner canyon stations corrected (GICS ${ }_{\text {corr }}$ ) seasonal depth-intensity relations.

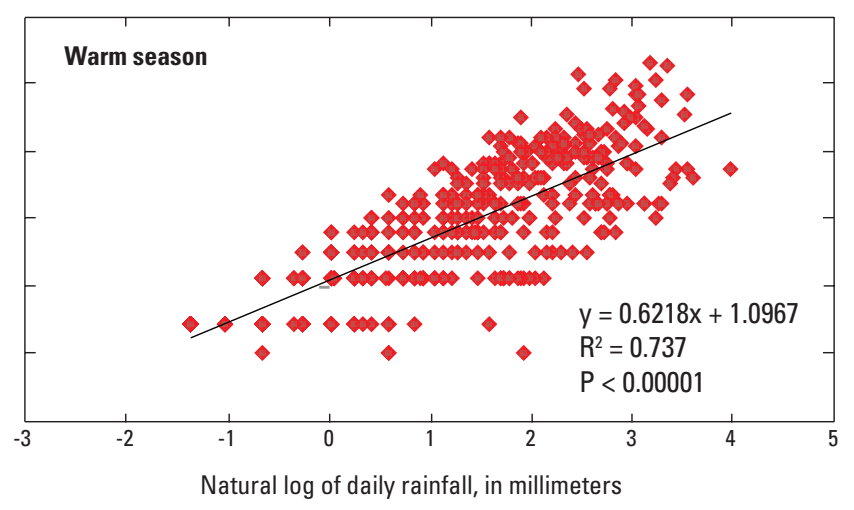

Figure 3-3. Plot of Marble Canyon Gauge Network on the Kaibab Plateau (MCGN -Kaibab) seasonal depth-intensity relations. 

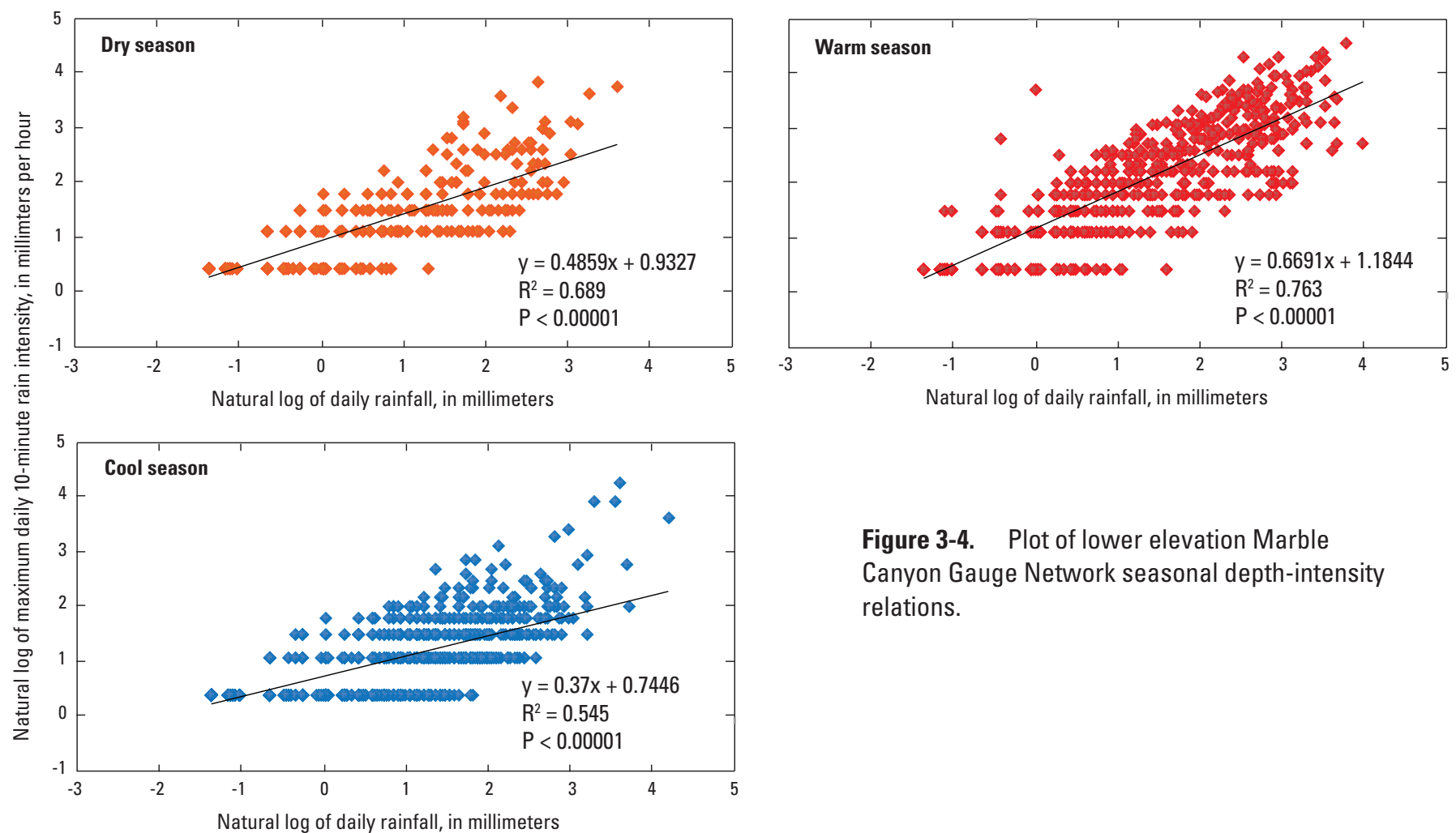

Figure 3-4. Plot of lower elevation Marble Canyon Gauge Network seasonal depth-intensity relations. 
Menlo Park Publishing Service Center, California

Manuscript approved for publication January 25, 2016

Text edited by Kate Jacques

Layout by Cory Hurd 


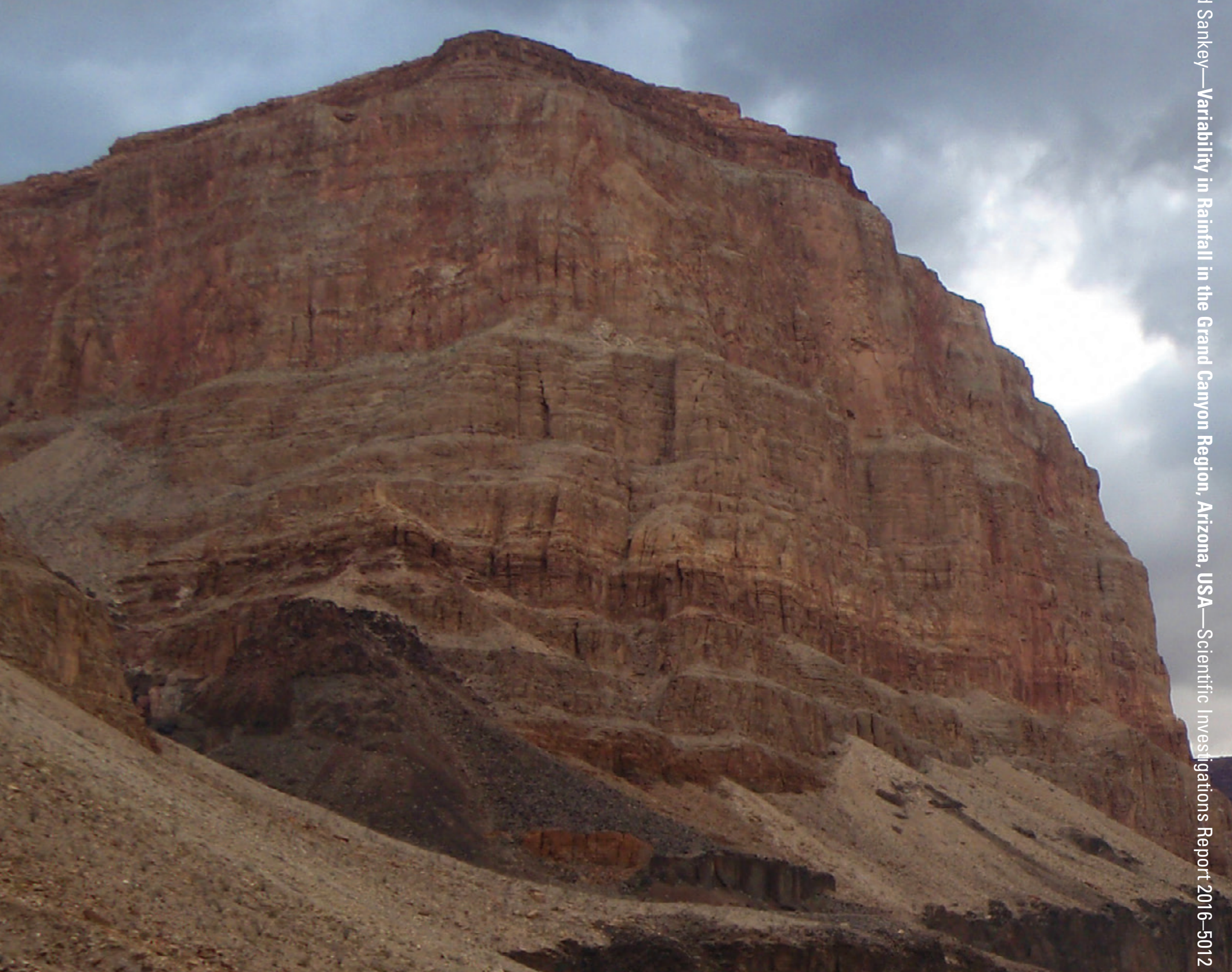

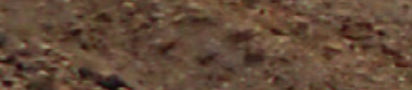

tostions?

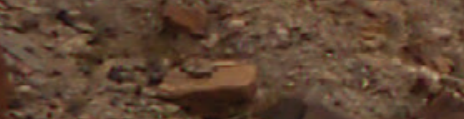

cax $x-2 x^{2}+2=0$

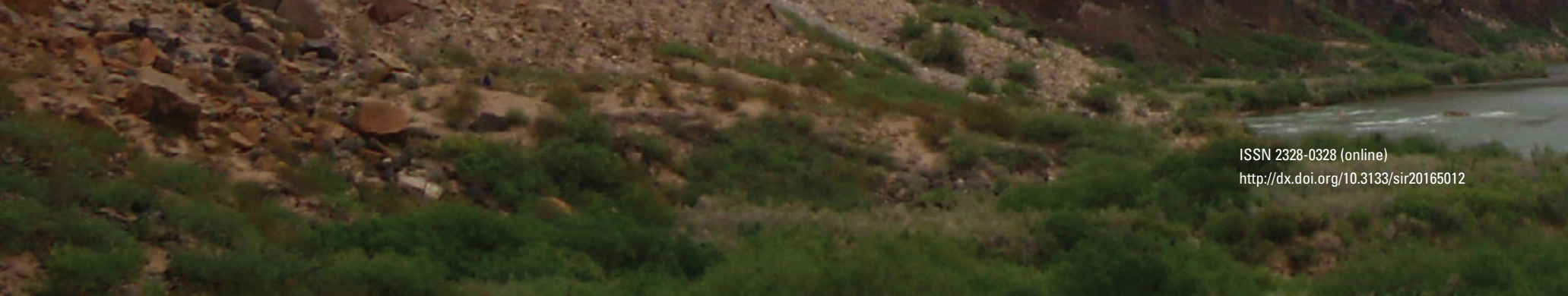

